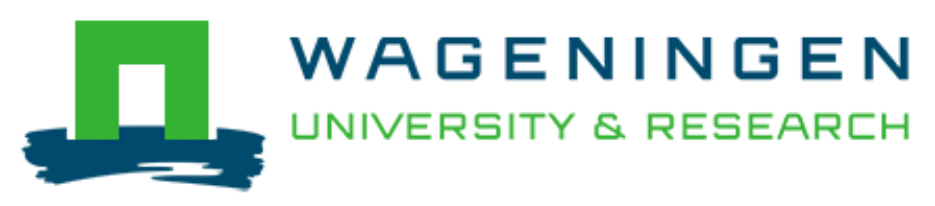

\title{
Seed degeneration of banana planting materials: strategies for improved farmer access to healthy seed
}

Jacobsen, K., Omondi, B. A., Almekinders, C., Alvarez, E., Blomme, G., Dita, M., ... Staver, C.

This article is made publically available in the institutional repository of Wageningen University and Research, under article 25fa of the Dutch Copyright Act, also known as the Amendment Taverne.

Article $25 \mathrm{fa}$ states that the author of a short scientific work funded either wholly or partially by Dutch public funds is entitled to make that work publicly available for no consideration following a reasonable period of time after the work was first published, provided that clear reference is made to the source of the first publication of the work.

For questions regarding the public availability of this article, please contact openscience.library@wur.nl.

Please cite this publication as follows:

Jacobsen, K., Omondi, B. A., Almekinders, C., Alvarez, E., Blomme, G., Dita, M., ... Staver, C. (2019). Seed degeneration of banana planting materials: strategies for improved farmer access to healthy seed. Plant Pathology, 68(2), 207-228.

https://doi.org/10.1111/ppa.12958 
REVIEW

\title{
Seed degeneration of banana planting materials: strategies for improved farmer access to healthy seed
}

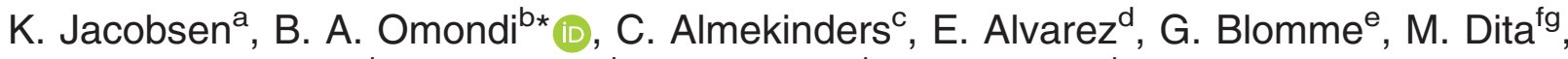 \\ M.-L. Iskra-Caruana ${ }^{h}$, W. Ocimati', W. Tinzaara', P. L. Kumar and C. Staver ${ }^{\mathrm{g}}$ \\ ${ }^{a}$ Royal Museum for Central Africa, Tervuren, Belgium; ${ }^{b}$ Bioversity International, c/o IITA Campus, 08 BP 0932 Cotonou, Benin; ${ }^{c}$ Faculty of \\ Social Science, Wageningen University and Research, Wageningen, Netherlands; ' $C e n t r o$ Internacional de Agricultura Tropical (CIAT), \\ Apartado Aéreo 6713, Cali, Colombia; ${ }^{\circledR}$ Bioversity International Addis Office, c/o ILRI, Addis Ababa, Ethiopia; ${ }^{\dagger}$ Embrapa Mandioca e \\ Fruticultura, Bahia, Brazil; ${ }^{9}$ Bioversity International, Montpellier, France; ${ }^{\mathrm{h}}$ CIRAD, Campus International de Baillarguet, 34398 Montpellier \\ Cedex 5, France; 'Bioversity International, Kampala, Uganda; and İIternational Institute of Tropical Agriculture, Ibadan, Nigeria
}

Vegetatively propagated crops suffer from yield loss and reduced stand density and longevity caused by the build-up of certain pests and pathogens between successive plantings via infected planting material. Here, six seedborne phytosanitary problems of banana are reviewed to evaluate whether a seed degeneration framework is a useful tool to identify approaches to achieve healthier planting materials. Phytoparasitic nematodes and weevils generate gradual declines in yields and in sucker health. Fusarium wilt and banana bunchy top virus cause progressive mat collapse across the field. Symptomless suckers from any mat in infested fields represent a risk of transmitting the disease to a new field. Xanthomonas and ralstonia wilts, due to incomplete systemicity, are intermediate in their threat to yield loss and frequency of transmission in suckers. Losses to banana streak virus are triggered by abiotic stress, although sucker transmission of episomal banana streak virus also contributes. A qualitative equation described here for seed degeneration covers a cycle beginning with the quality and risk factors of the planting material used to plant a new field and ends with the quality and risk factors of the suckers extracted from the field to plant a new field. This review of five planting material multiplication methods commonly used in banana contrasts their differing usefulness to address seed degeneration in the small farm context. It is proposed that initiatives to offset banana seed degeneration should integrate the role of off-farm actors into decentralized initiatives rather than attempt to duplicate national seed certification frameworks from other true seed or vegetatively propagated crops.

Keywords: infection, propagation, seed-health, suckers, systemicity

\section{Introduction}

Bananas (Musa spp., including plantains), like other vegetatively propagated crops, suffer yield loss and reduced stand density and longevity caused by certain pests and pathogens that are transmitted from field to field through infected planting material. The semiperennial nature of banana plantations and the banana plant growth habit distinguish it from other root and tuber food crops such as yam, cassava, potato and sweet potato. The initial planting material, often a corm, produces a mother pseudostem that generates numerous secondary plants or suckers. All the pseudostems and suckers originating

*E-mail: b.a.omondi@cgiar.org

Published online 5 December 2018 from an initial mother pseudostem over successive harvests are together referred to as a mat. The production of banana is based on the selection of a sucker to become the new mother plant after the main stem has produced fruits. Left in place, each of these lateral shoots produces a bunch and in turn, a new set of suckers. For new field establishment, suckers from mats in existing fields are detached, possibly treated (e.g. corm paring or hot/boiling water treatment), transported to the new field and planted to become a new mat. Thus, suckers (vegetative 'seed') are a primary vehicle for the spread of soilborne and systemic pests and pathogens.

This paper examines the consequences of the seedborne pest and pathogen complex on the quality and performance of planting material. The loss of quality of planting material due to seedborne pests and diseases has been referred to as seed degeneration, a term first coined to refer to the accumulation of viral infections in potato planting materials following seasons of vegetative 
propagation with gradual and almost imperceptible yield loss (Schulz \& Folsom, 1923). Struik \& Wiersema (1999) extended seed degeneration to include non-viral pathogens. Thomas-Sharma et al. (2016) most recently defined seed degeneration as 'the reduction in yield or quality caused by an accumulation of pathogens and pests in planting material due to successive cycles of vegetative propagation'.

Banana production shares many key management practices with potato and other root and tuber crops. Clean planting material has long been recognized as important in avoiding yield loss (e.g. Colbran, 1967; Tenkouano et al., 2006). To ensure seed quality, scientists and practitioners working on vegetatively propagated crops have emphasized seed certification as part of the solution. Seed certification programmes for banana have been implemented in only a few regions such as Australia and India (Singh et al., 2011) and on a trial basis in certain regions of Asia and the Pacific (Molina, 2004) and the Caribbean (Bortagaray \& Gatchair, 2012). The focus of certification is primarily on globally traded, tissue culture (TC)-based planting material, accounting for less than $2 \%$ of banana planted. Most banana farmers are smallholders who source suckers, often sporadically and in relatively small quantities, from their own fields or from neighbours (e.g. Banful, 2000; Shamebo, 2000; Staver et al., 2010; Ocimati et al., 2013a). Such informal or farmer seed systems are adaptively flexible, with a mix of cultivars suited to local use (e.g. Almekinders et al., 1994; Karamura et al., 2004). Because suckers are bulky and perishable, local sourcing is practical and cost effective. However, the capacity of the local seed system is easily exhausted when large quantities of planting materials are needed (Staver et al., 2010). High demand for planting material occurs in three contexts, when: (i) emerging diseases spread into new areas generating a demand for planting material for rehabilitation; (ii) projects for poverty reduction or disaster recovery include the distribution of large amounts of planting material; and (iii) emerging market opportunities prompt a more uniform or diverse production requiring large quantities of existing or new cultivars. Thousands or millions of disease-free suckers can rarely be sourced from local systems for timely seasonal distribution in any of these three situations. Staver et al. (2010) proposed that investments in improved quality of planting material should be location specific and respond to diverse factors, including cultivar diversity, the pests and pathogens present locally and the available infrastructure.

The goal of this review is to evaluate whether a seed degeneration framework is a useful tool to identify approaches and knowledge gaps to achieve healthier planting materials. First, a systematic review of the major pests and pathogens affecting banana planting material quality is undertaken. Based on the review, a set of factors formulated as an equation to monitor the rate of degeneration are then proposed. The mechanisms of five different sucker multiplication methods are also considered to address seed degeneration in the small farm context. This review then illustrates how the proposed framework applies in five case studies. While the case studies draw on literature, the major source of information is the direct experience among different authors in these sites. The application of the framework to the case studies provides the input for the conclusions on emerging approaches and key research needs to improve quality planting material and reduce the seed degeneration rate.

\section{Pests and pathogens transmitted through banana planting materials}

This section first describes six major seedborne pests and pathogens of banana and their distribution and damage, and then compares and contrasts them based on the following questions to identify factors affecting phytosanitary quality of planting material (Table 1).

- What are the components of yield loss due to the causal organism?

- How does the causal organism survive and spread and what is the relative role of planting material?

- How does sucker infection occur?

- Do cultivars, including improved cultivars, have different susceptibilities to the different pests and pathogens?

- What tools and methods are available for detection of the causal organism?

- What on-farm practices address the threat of yield loss or seed degeneration from the organism?

\section{Common banana pests and pathogens in planting material}

Six major banana phytosanitary problems are analysed here: nematodes, weevils, bacterial wilts, fusarium wilts, banana bunchy top disease and banana streak disease (Table 1).

\section{Plant-parasitic nematodes}

Plant-parasitic nematodes are pantropical, although species composition is determined by multiple factors and on different scales: large-scale factors (national quarantine efficiency, endemic versus emerging species), regional factors (geography, climate) and local factors (soil type, cropping system). For bananas, endoparasitic lesionforming nematodes (Radopholus similis, Pratylenchus goodeyi, Pratylenchus coffeae) are generally more damaging than root knot nematodes (Meloidogyne spp.), semi-endoparasites and ectoparasites (Helicotylenchus dibystera, Helicotylenchus multicinctus and Hoplolaimus pararobustus). Root damage may present as reddishbrown lesions along the root cortex and the outer corm cortex or galling of the roots. The severity of damage depends on the nematode population densities, pathogenicity of the species involved, susceptibility of the Musa cultivar and suitability of the environment. Aboveground damage is indistinctive, resulting from an impaired uptake of nutrients by the plant following root damage. Extreme root damage may lead to toppling of the plant due to poor anchorage (Sarah et al., 1996; 


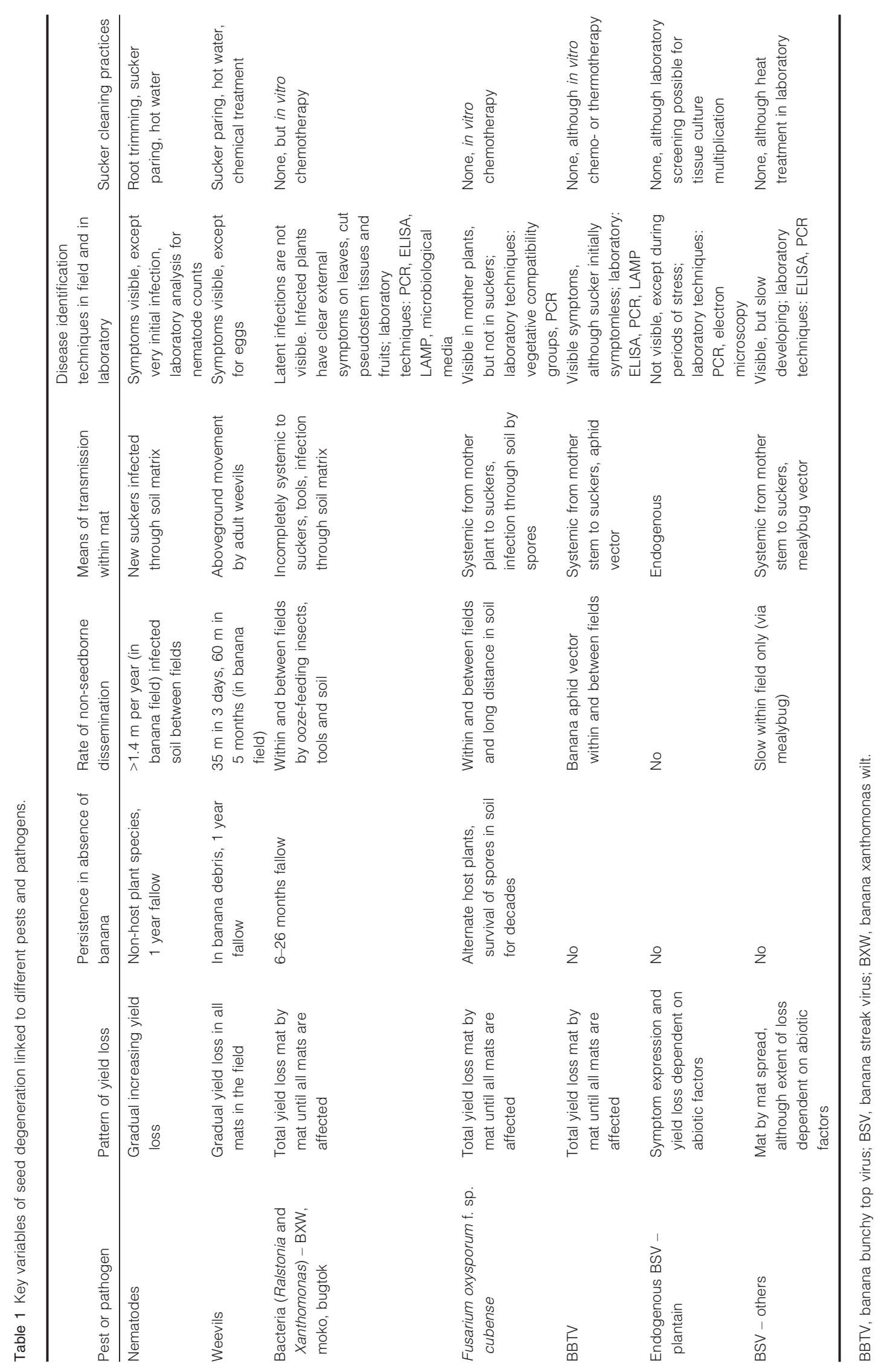


Gowen et al., 2005; Duncan \& Moens, 2006). Nematode damage may be mitigated by factors associated with vigorous growth, e.g. rainfall and soil fertility which promote root growth, while plant stress exacerbates damage (Hauser, 2000; Gowen et al., 2005).

\section{Banana weevil}

The banana weevil (Cosmopolites sordidus) is the only insect pest transmitted through planting materials. Of the insects affecting bananas, the larvae of the banana weevil cause the most direct damage. Adults lay eggs in the leaf sheaths and on the rhizome surface. Larvae feed on the corm generating a progressively denser network of tunnels, which impair water and nutrient movement, and weaken corm structure. The result is poor growth, low bunch weights, susceptibility to drought, corm snapping, reduced suckering and shorter plantation lifespan. Originally from Southeast Asia, banana weevils are now a problem in most banana-producing regions (Gold \& Messiaen, 2000).

\section{Bacterial wilts}

Bananas are severely affected by two wilt-inducing bacterial genera: Ralstonia and Xanthomonas. All bacterial wilts characteristically cause leaf yellowing and wilting caused by blocking of vascular bundles in the corm and pseudostem, dry rot of the male inflorescence part and internal browning of the fruit pulp. Stem discolouration and bacterial ooze in the cut pseudostem, leaf petioles and corm are also common features of bacterial wilts, although with variations in ooze colour and abundance (Blomme et al., 2017). Different bacterial wilts are present in Asia, Africa and Latin America. Some locations in each continent are free of the wilts considered here. Ralstonia solanacearum is a heterogenous species causing vascular wilts in many species of plants. The diversity has been classified using three systems: biovars based on carbohydrate metabolism (Hayward, 1964), host races (Buddenhagen \& Elsasser, 1962) and phylotypes based on molecular sequence analysis of the 16S-23S rRNA (Fegan \& Prior, 2005). Those causing wilts in banana belong to biovars 1 and 3 (Hayward, 1991) or phylotype II (Fegan \& Prior, 2005). They have a high geographic and pathogenic diversity, resulting in variable disease expression and potential for diverse host-parasite genotype interactions depending on strain characteristics (Buddenhagen, 1986, 2009; Gomez et al., 2006; Valencia et al., 2014; Álvarez et al., 2015a). Ralstonia wilt is found in Latin America and the Caribbean where it is known as moko, and Southeast Asia (moko/bugtok and blood disease), but currently not in Africa (Buddenhagen, 1994; Denny, 2006; CAB International, 2014). In the Philippines, wilt disease caused by $R$. solanacearum is named depending on symptom expression. When $R$. solanacearum is transmitted by insects visiting the flower, symptoms occur mainly in the inflorescence and are called bugtok. Tool-mediated transmission results in mainly leaf and stem symptoms, called moko disease (Eden-Green, 1994a; Ilagan et al., 2003). In Indonesia and New Guinea, banana blood disease caused by $R$. solanacearum affects dessert and local cooking bananas (Stover \& Espinoza, 1992; Eden-Green, 1994b; Davis et al., 2001). Xanthomonas wilt is endemic to Africa, originating in Ethiopia and now found throughout East and Central Africa (Smith et al., 2008; Tripathi \& Tripathi, 2009; Karamura et al., 2010).

\section{Fusarium wilts}

Different races of Fusarium oxysporum f. sp. cubense (Foc), the causal agent of fusarium wilt, are defined by their potential to affect different subgroups of Musa spp. Race 1 affects mainly Gros Michel and Silk but not Cavendish; race 2 affects bananas of the Bluggoe (ABB) subgroup. The full inventory of cultivars susceptible to tropical race 4 (TR4) is still being completed (Walduck \& Daly, 2007; Zuo et al., 2018); some tolerant somaclonal variants of the Giant Cavendish tissue culture variants (GCTCVs) have been developed in Taiwan (Hwang \& Ko, 2004). East African Highland varieties have already been cited as fairly tolerant (Zuo et al., 2018). Two transgenic Cavendish lines have been recently reported resistant to TR4 (Dale et al., 2017b). TR4 tolerant variants of the GCTCV express lower levels of TR4 resistance genes homologous to the transgenic varieties, highlighting possibilities of gene editing to increase non-transgenic resistance to the disease (Dale et al., 2017 b). TR4 also affects both race 1 - and race 2-susceptible cultivars (Ploetz, 2006) and Barangan (AAA) and Pisang Mas (AA) (Hermanto et al., 2011).

Foc strains are also characterized in over 21 different vegetative compatibility groups (VCGs), with the majority of groups present in Asia, where the pathogen is thought to have originated (Puhalla, 1985; Ploetz \& Pegg, 1997; Bentley et al., 1998; Fourie et al., 2009). While TR4 is restricted to the Philippines, Malaysia, Indonesia, Australia, China, Pakistan, Lebanon, Oman and Mozambique, races 1 and 2 are found in almost all banana-growing regions, with regional differences on disease intensity due to different VCG distribution. Focinfected plants first lose turgor and then leaves begin to yellow, usually older leaves first, as a result of blocking of vascular flows of water and nutrients. Pseudostem splitting is often seen, bunches fail to fill out and reddish brown mycelia increase in frequency in the corm and pseudostem. Suckers are also infected as the disease spreads in the mat, but apparently healthy suckers not yet showing symptoms are commonly used for new plantations, thus spreading the pathogen to new areas.

\section{Banana bunchy top disease}

Banana bunchy top disease (BBTD) is caused by the multicomponent circular single-stranded (ss) DNA banana bunchy top virus (BBTV), from genus Babuvirus of the family Nanoviridae (King et al., 2012). This virus is considered the most serious of the viral diseases affecting banana (Rybicki, 2015) and one of the top 10 invasive viruses impacting crop plants across the world (Global Invasive Species Database, 2018). BBTV has been a 
major concern in many Asian and Pacific countries since the 1990s. BBTV was first reported in Central Africa in 1958 (Wardlaw, 1961) and is currently found in at least 16 countries on the continent (Kumar et al., 2011, 2015; Jooste et al., 2016).

Banana bunchy top virus is a systemic virus restricted to the phloem tissues. Suckers produced by an infected mat and young plants infected by aphid vectors, Pentalonia nigronervosa, develop severe symptoms well before reaching maturity (Magee, 1927). Early symptoms (i.e. dark green discontinuous streaks on leaves and petioles) are sometimes barely detectable, and their expression may be clearer in some cultivars than others. Advanced symptoms include shortening of the internodal length and narrowing and shortening of younger leaves, giving the plant a typical bunchy appearance. The movement and trade of infected planting materials is a key route for the introduction of BBTD into new regions, often associated with weak phytosanitary regulations (Stainton et al., 2015), while aphid transmission and planting material spread the disease over short distances. These planting materials are symptomless, or have symptoms not recognized as risky by farmers.

\section{Banana streak disease}

Banana streak disease is caused by a species complex of banana streak viruses (BSVs) belonging to the genus Badnavirus, family Caulimoviridae. BSV is a pararetrovirus characterized by a high genetic diversity (Harper et al., 2004; Gayral \& Iskra-Caruana, 2009; Iskra-Caruana et al., 2014a). Although distributed in all banana-growing areas in the world (Diekmann \& Putter, 1996), BSV only rarely causes economically important losses (IskraCaruana et al., 2014b). BSV occurs in two different infectious forms: (i) the episomal form, which is transmitted through infected planting materials and by at least six mealybug species, including Planococcus citri and Planococcus minor (Daniells et al., 1995); and (ii) the endogenous BSV viral sequences (eBSV), which are integrated within the banana B genome (Iskra-Caruana et al., 2010; Kumar et al., 2015). These sequences, which are usually silent, may be activated when exposed to an abiotic or biotic stress such as changes in temperature and in tissue culture. Symptoms on the leaves can be seen as chlorotic streaks, either continuous or discontinuous. Dark blotches may be seen on the petioles, indicating necrosis in the vascular tissues. Plants sometimes show symptoms such as pseudostem splitting, lengthening of the growth cycle or cigar leaf necrosis (Thangavelu et al., 2000). In severe infections, aberrant bunch emergence, peel splitting and rarely plant death have been observed. Symptom severity of BSV depends on a variety of factors including virus isolate, cultivar, crop management and environmental conditions (Lockhart, 1986; Gauhl \& Pasberg-Gauhl, 1995; Dahal et al., 1998a,b; Lockhart \& Jones, 2000).

Of all seed degenerative pathogens, only BSVs and xanthomonas wilt are known to show some signs of reversion (host recovery from disease symptoms). As BSV is endogenously incorporated into the $\mathrm{B}$ genome, its reversion or return to inactive state occurs intracellularly, and may be influenced by the environmental conditions or depend on pathogen strain. The titre of BSV may fluctuate depending on banana plant defence regulation when they have eBSV in their genome (author's unpublished data). However, the titre of xanthomonas wilt tends to decrease over successive generations (Ocimati et al., 2015).

\section{Components of yield loss due to the causal organism}

Although bananas are increasingly grown in higher density stands for only one to two harvests, most fields are planted with the expectation of at least three harvests, and stands are often perennial. Yield loss due to pests and pathogens generally become a bigger constraint as the stand ages (McSorley \& Parrado, 1986; Hauser, 2000; Gold et al., 2002b), which complicates the measurement of yield loss. The yield gap is also affected by the degree of initial infection in planting materials. Nonetheless, diverse studies provide pest and pathogenspecific estimations of overall yield loss. Weevil damage has resulted in more than $30 \%$ reduced bunch weight, $17-50 \%$ higher premature plant death rates, toppling or snapping and lengthening of the growth cycle (Rukazambuga et al., 1998; Gold \& Messiaen, 2000; Ysenbrandt et al., 2000; Messiaen, 2002). For bacterial wilts, yield losses up to $100 \%$ may be observed, as infected mother plants most often deteriorate progressively and die, or bunches become unmarketable. Average yield losses from banana blood disease may exceed 35\% (Supriadi, 2005). In south Sulawesi, up to $80 \%$ of plantations were lost (Roesmiyanto \& Hutagalung, 1989), and in west Java, up to $36 \%$ plantation loss was recorded (Muharam \& Subijanto, 1991). Xanthomonas wilt caused up to $50 \%$ yield loss in affected farms in East and Central Africa (Kalyebara et al., 2006; Karamura et al., 2010). Moko disease has seriously reduced plantain production in the main growing areas of Colombia, causing losses of up to $100 \%$, forcing many farmers to substitute this crop with fruit trees, due to lack of options for disease control and eradication (Álvarez et al., 2015a). Infection with TR4 has led to the abandonment of Cavendish banana production in China after total yield collapse and high levels of residual inoculum in the soil, similar to the situation with Gros Michel affected by Foc race 1 in Latin America and the Caribbean decades earlier (Ploetz, 2015). For BBTV between 1994 and 2000, Cavendish banana production declined by $80 \%$ in central and southern Malawi, with income loss for rural communities and banana price increase for urban consumers (Kumar et al., 2011). Similar reductions have been reported in the Lukaya and Cataractes districts in the Democratic Republic of Congo, where BBTV reduced production from 2000 bunches per month prior to BBTV to 30 after BBTV had spread, and entire villages abandoned banana production (Vangu Phaka, INERA, Mvuasi, DRC, personal communication). Damage caused by BSV in 
episomal form can be severe, with yield losses up to 90\% recorded for Poyo (AAA, Cavendish subgroup; Lassoudière, 1974) or mild, with symptomless infected plants or yield losses of merely $10 \%$ reported (Jones \& Lockhart, 1993; Daniells et al., 2001; Harper et al., 2002). These yield losses for the six causal agents, except eBSV, can be severe and are accompanied by the infection of suckers that, if used, are the source of infection for new fields.

At a field scale, the causal organisms show contrasting patterns of spread based on how completely mats lose productivity upon infection (Table 1 ). For weevils and nematodes, a mat continues to be productive even in the presence of the causal organism. Even if all mats in a stand are affected and yield declines, the field continues to produce bunches. Commonly, the field suffers a higher incidence of other problems such as toppling in the wind, greater propensity for plant stress and yield gaps associated with poor nutrient use. In bacterial wilts, incomplete systemic movement of bacteria from an infected pseudostem to physically attached suckers on the same mat occurs, leading to a combination of primarily healthy shoots with a few shoots latently infected or with symptoms (Black \& Delbeke, 1991; Soguilon et al., 1995; Ocimati et al., 2013b, 2014). Thus, the application of a disease management package based on three key practices - (i) removal of diseased shoots, (ii) tool disinfection, and (iii) early male bud removal - in fields with widespread xanthomonas wilt (BXW)-infected banana mats has led to full recovery of production (Blomme et al., 2017). By contrast, Foc- and BBTVinfected mats quickly cease to be productive. Yield decline occurs as the disease spreads within mats and across the field, turning more and more mats completely unproductive.

BSV is an outlier from the two patterns mentioned above. The severity of the infection depends on the BSV strain, the banana genotype and environmental conditions (Dahal et al., 2000; Dallot et al., 2001; Lheureux et al., 2003; Côte et al., 2010; Karanja et al., 2013). When the mother plant is infected with episomal BSV, all suckers are also progressively infected. However, in Cavendish plantations in Peru and Ecuador or East African Highland bananas in East Africa, the rate of spread of BSV from infected to uninfected mats was slow (Harper et al., 2004). For BSV resulting from eBSV, which is widespread in AAB banana and plantains, symptoms appear and disappear according to the rate of the infection regulated by the banana plant and abiotic conditions (Karanja et al., 2013). eBSV does not appear to spread from mat to mat due to the banana defence regulation of the infection.

\section{Survival and spread of causal organism and the relative role of planting material}

Infected planting material is a key source of infection for newly planted fields except for eBSV. However, the rate of spread within the field or the likelihood of infection even if completely clean planting material is used depends on additional factors that affect seed degeneration rates (Table 1 ).

An important factor is the history of banana cultivation in a field. While Foc chlamydospores can survive for decades in soil (Ploetz, 2015), a shorter survival period and therefore fallow or crop rotation period of $6-$ 12 months is recommended for nematodes (Tarjan, 1961; Chabrier \& Quénéhervé, 2003) and for xanthomonas wilt (Turyagyenda et al., 2008; Sivirihauma et al., 2013; Blomme et al., 2014), and 6-26 months for the ralstonia wilts depending on the strain and local conditions (Sequeira, 1962; Hyde et al., 1992; Denny, 2006). During this period, the field must be free of living banana tissue. Some nematodes, e.g. R. similis and Pratylenchus spp., may remain resident in a field on nonMusa hosts, such as weeds and other crops (Prasad et al., 1995; Quénéhervé et al., 2005). BBTV and BSV survive only in living banana tissue and insect vectors, and a banana-free period ensures not only a disease-free field, but is also aimed at ensuring vector die-off. Alternative hosts for these viruses are as yet unknown.

The challenge of cost-effective eradication of an infected banana mat is common to the phytosanitary problems reviewed here. Rapid elimination of potentially infected mats is essential for rotations to counteract nematodes, weevils (Chabrier \& Quénéhervé, 2003), bacterial wilts, BBTV and BSV in A genome cultivars. Timely roguing is equally important for fusarium wilts, despite the longer survival time of chlamydospores in the soil (Dita et al., 2018). Chabrier \& Quénéhervé (2003) showed that herbicide destruction of old banana mats reduced the number of nematode-infected plants in the following banana crop by more than $50 \%$, whereas with mechanical destruction the emergence of volunteer shoots remained problematic.

A second factor is the effective distance from the source at which infection can occur. Soil and water movement aid the dispersal of soil pathogens such as nematodes, bacteria and Foc chlamydospores (Sarah et al., 1996; Denny \& Hayward, 2001; van Elsas et al., 2005; Tenkouano et al., 2006; Álvarez et al., 2015a; Ploetz, 2015). This includes irrigation water, overland flow and flow in gullies associated with soil erosion and floods. This risk for Foc is substantially higher, due to the longer survival time for chlamydospores, and infected soil on shoes or any other object that can move between continents (Buddenhagen, 2009). The droplets of bacterial ooze forming on cuts and scars left where bracts of banana flowers have fallen off attract insects, such as stingless bees, Trigona spp. (Buddenhagen \& Elsasser, 1962). Insect vectors attracted to the sweet sap containing bacteria can transmit bacterial wilt up to $100 \mathrm{~km}$ in 1-2 years (Buddenhagen \& Elsasser, 1962). Bacterial ooze can also be moved from field to field on tools such as cutlasses, hoes and debudding knives (Blomme et al., 2014; Álvarez et al., 2015a). Allen (1978) estimated that the banana aphid can transmit BBTV from a primary source to a mean distance of $15.2 \mathrm{~m}$ with little annual spread beyond $100 \mathrm{~m}$. However, aphids can drift over 
even longer distances in wind currents with a distinct, but remote, potential to infect new fields. Weevils move much shorter distances, with very few $(<3 \%)$ weevils travelling across banana-free zones wider than $32 \mathrm{~m}$ (Wallace, 1938; Gold et al., 1998, 2004).

Within-field movement involves the movement by contaminated soils and water for Foc, bacterial wilts and nematodes, vector transmission by banana aphids for BBTV and mechanical transmission by diverse oozefeeding insects and contaminated tools for bacterial wilts. Nematodes move freely at $>1.4 \mathrm{~m}$ per year (Duncan \& Moens, 2006). Weevils were reported to move about $35 \mathrm{~m}$ every 3 days (Gold \& Bagabe, 1997), although Delattre (1980) reported 60 m every 5 months. The movement of $X$. campestris by weevils has been documented (Were et al., 2015), while both nematodes and weevils have also been shown to move Foc from mat to mat (Speijer \& Sikora, 1993). Mealy bugs, the primary vector of BSV, also move primarily within fields.

\section{How does within-mat transmission to the sucker occur?}

The transmission of pathogens/pests to suckers occurs in three different ways: contamination with spores or pests from the soil, movement within the mother plant tissue to all suckers (complete systemicity) and only to some suckers (incomplete systemicity). Suckers are infected with nematodes and weevils from the soil matrix, with no direct movement corm to corm through plant tissue. BBTV, Foc and eBSV are systemic. The presence of the pathogen in the mother stem ensures infection of all suckers, although there may be a time lag in the appearance of the symptoms. Djialo et al. (2016) found that the rate of BBTV infection of symptomless suckers in banana mats with different severity levels as judged by visual symptoms was between $23 \%$ and $70 \%$. Although BBTV presence was less frequent in mats with less symptoms, even at very low symptom expression in mother stems, the risk of disease presence was still too high for use as planting material without further testing. For Foc, the lack of a simple diagnostic test for different races and VCGs makes such testing difficult. The risk associated with the use of suckers from fields with a low incidence of Foc has not been quantified. Finally, in the third group (bacterial wilts), the risk of cryptic infection of suckers differs by species and strain of bacterial wilt. Incomplete systemicity has been reported for xanthomonas wilt (Ssekiwoko et al., 2010), bugtok (Soguilon et al., 1995) and moko (Black \& Delbeke, 1991), although Álvarez et al. (2015b) indicate that Ralstonia is systemic with a high risk of transmission in suckers. Recent studies by Sivirihauma et al. (2017) observed that roughly $80 \%$ of symptomless suckers taken from mats with diseased stems produce a plant free of disease at harvest, suggesting that suckers from diseased fields can serve as planting material in zones with no access to clean planting materials. However, to prevent the risk of introducing suckers with latent infection, such suckers should not be planted in areas where the disease has not yet been reported (Sivirihauma et al., 2017).

\section{Cultivar differences in susceptibility to seedborne pests and pathogens}

Cultivar differences in disease and pest susceptibility have implications for seed degeneration rates and seed management approaches to reducing losses. Cultivar substitution based on differences in susceptibility needs to take into account production and economic factors, because the fruit of more resistant cultivars may not have the same use, processing or market opportunities as susceptible cultivars. While certain cultivars may be more resistant to one or two of these problems, they may also be more susceptible to others, reducing their substitutability. The Cavendish cultivar successfully replaced Gros Michel to address Foc race 1, but Cavendish has shown greater susceptibility to nematodes and black leaf streak.

Breeding for resistance is a common strategy to address seed degeneration. Cultivar resistance through breeding figured predominantly in a recent proposed approach to address seed degeneration in potato (Thomas-Sharma et al., 2016). Numerous factors have slowed the use of breeding to improve pest and disease resistance in banana and thereby reduce problems of seed degeneration. Breeding programmes have largely focused on resistance to black leaf streak (Tirado \& Zapata, 2003; Bakry et al., 2009), although cultivars have commonly been screened as well for nematode, weevil and Foc resistance. Genetic modification and gene editing have offered new promise for resistance through breeding, although the time line is uncertain (Dale et al., 2017a). Proof-of-concept transgenic banana lines have been developed for resistance to xanthomonas wilt (Tripathi et al., 2010; Namukwaya et al., 2011), TR4 (Hwang \& Ko, 2004; Dale et al., 2017b), BBTD (Elayabalan et al., 2015) and nematodes (Tripathi et al., 2015). The use of these lines could either reverse degeneration completely (complete resistance) or increase the threshold at which symptoms would appear (Ghag et al., 2015). A recent desk review looked at the potential for diverse breeding methods to address pest and disease losses in banana (Staver \& Capra, 2017). This section emphasizes currently available cultivars, whether from crop diversity or breeding.

For nematodes, resistance may be full or partial, and 'resistant' cultivars may react differently to different pathotypes (Dochez et al., 2006; Thompson et al., 2008). Cultivar differences have been recorded in weevil survival rate and larval development (Sadik et al., 2010). Hardness of the corm (Kiggundu et al., 1999) and a possible antibiotic effect exerted on developing weevil larvae (Lemaire, 1996) have been suggested as components of resistance. However, few marketable resistant cultivars have been identified.

For moko, the plantain hybrid FHIA-21 in Colombia showed excellent tolerance levels and a notable absence 
of typical symptoms (Álvarez et al., 2015a; Vitovec, 2015). No cultivars resistant to xanthomonas wilt have been reported in East and Central Africa, although East African Highland AAA bananas and AAB plantains are less susceptible to insect-mediated infections than $\mathrm{ABB}$ and $\mathrm{AAB}$ dessert cultivars (Karamura et al., 2010).

The various races of Foc have different variety susceptibility spectra. Cultivar substitution, Cavendish for Gros Michel in the export industry, has been used to address Foc race 1 . Foc race 2-resistant Sabah and Pelipita are often substituted for race 2-susceptible Bluggoe in Central America and the Caribbean. For TR4 the potential for cultivar substitution as a management strategy is still unknown. For Foc race 1, Brazil's Embrapa has released numerous lines with improved resistance (Amorim et al., 2013). Clonal variation has been harnessed through repeated selection in growers' fields and experimental fields to develop the GCTCVs tolerant to fusarium wilt (Hwang \& Ko, 2004), which are being increasingly planted in TR4-infested soils.

All cultivars are susceptible to BBTV, but variation in symptom expression and susceptibility to infection have been observed. Musa cultivars with the B genome (AAB and $\mathrm{ABB}$ ) are seen to decline less rapidly than those with only the A genome (AA and AAA) (Jose, 1981; Espino et al., 1993). However, aphid preference for banana/plantain varieties may also determine the risk of field infection, potentially confounding BBTV tolerance observations (Ngatat et al., 2017). Somewhat tolerant cultivars remain hosts for BBTV and a potential reservoir for infection that may prevent the successful reintroduction of susceptible cultivars (Niyongere et al., 2011).

The challenge of multiple resistance can be illustrated with the case of ABBs, which are highly resistant to weevils and nematodes (Gold et al., 2001). Also characterized by abundant suckering, cultivars such as Pisang Awak and Bluggoe are very persistent. However, both cultivars are highly susceptible to insect-mediated bacterial wilt infections and Foc, and in the presence of the latter two problems, production system collapse occurs.

\section{What tools are available for detection of the causal organism?}

Pest detection has two dimensions: on-farm diagnostics and laboratory testing procedures. Detection of symptoms is the most practical means of crop disease management, but its use to reduce seed quality degeneration depends on the extent to which visual symptoms can be used accurately to detect the presence of phytosanitary problems in the field either by growers, traders or certification agencies. In practical management terms, two questions are important. Can symptom identification support positive selection/roguing-based management to meaningfully reduce disease incidence or delay the seed degeneration at farm level? Can laboratory procedures contribute to more effective management of the quality of planting material in strategies to redress degeneration? The management of seedborne disease depends on the effectiveness of any diagnosis in aiding risk avoidance as much as possible in the use of locally available materials or in limiting infection of clean materials planted.

For nematodes and weevils, complete absence of the pest in field-extracted suckers cannot be ensured by visual examination. Weevil eggs and very early phases of nematode infestation are not visible, but visual detection of the earliest symptoms in the roots and corms is straightforward for growers and field technicians. Laboratory analysis for nematodes is necessary to estimate nematode population densities and species composition (Hooper et al., 2005). Such estimates need to rely on consistent sampling plans, e.g. only sampling the mother plant, sampling at specific time intervals or host phenological stage. Weevil pressure can be estimated either by assessment of corm damage or determining weevil populations by trapping (Messiaen, 2002).

Visual detection of bacterial wilt symptoms in the mother plant will miss the early latent infection phase, but afterwards early detection of symptoms is straightforward. Microbiological media-based methods (Kelman, 1954; Roberts et al., 1990; Mwebaze et al., 2006) have been developed for the isolation and detection of bacteria in plant tissues. Molecular methods, such as real-time quantitative PCR, PCR, and a loop-mediated isothermal amplification assay (LAMP; Kubota et al., 2008) are used for specific detection of Ralstonia in symptomless plants, soil and water, and also to classify phylotypes and sequevars (Thwaites et al., 1999; Prior \& Fegan, 2005; Hodgetts et al., 2015). ELISA-based methods (Nakato et al., 2013) and a lateral flow device (Hodgetts et al., 2015) have been developed for rapid detection of Xanthomonas.

Both field and laboratory identification of Foc is complicated for early and precise identification. In the field, fusarium wilt can sometimes be confused with bacterial wilts, but the early latent phase is even more difficult to detect because clear symptoms are often expressed only at flowering. No studies exist on the risk of Foc in suckers resulting from different exposures to Foc in stems or mats, because simple detection is not possible and symptom expression may be delayed by months. Cryptically infected suckers remain a considerable constraint to the seed systems (Ploetz, 2015). Laboratory protocols for identification of VCGs are available, but time-consuming, expensive and dependent on the availability of the VCG markers. A PCR-based diagnostic tool is currently available for Foc TR4 (Dita et al., 2010).

The earliest symptoms of BBTV, which appear on the leaf petioles, are easier to detect in newly planted suckers or tissue-cultured plants than in older plants; and on Cavendish or AAA genotypes than on plantain or $\mathrm{AAB}$ and ABB genotypes. On-farm diagnosis for BBTV based on more advanced symptoms does not support effective control. Depending on the time of infection, mats infected by BBTV may yield some symptomless suckers (Kumar et al., 2015). While such symptomless suckers 
are a very high risk for infection of new plantings, the detection and roguing of infected suckers based on earliest symptoms on the petiole (dot and line pattern) is possible for Cavendish before banana aphids are able to acquire and transmit the virus (Allen, 1978). ELISA kits for the detection of BBTV in the field are commercially available and can be read visually in the field or with a reader (Caruana, 2015). PCR, immunocapture (IC-) PCR and LAMP analysis, also available, cannot be done in the field, but offer superior sensitivity and flexibility (Caruana, 2015).

The first BSV symptoms can readily be observed as light translucent dots under the leaf. They evolve into yellow streaks turning into necrotic spots on the leaf lamina. PCR diagnosis can be used on samples having only A genomes. To detect eBSV, IC-PCR using a DNase step to eliminate plant DNA residues is the only test available (Thomas, 2015). Efforts are on-going to develop field-ready quick diagnostic techniques based on LAMP.

\section{Practices to reduce the risk of infection and eliminate the causal organism in the banana sucker}

The build-up of nematodes and weevils is easiest to manage on-farm, greatly reducing the risk of seed degeneration. Diverse practices to reduce nematode build-up include use of green manure intercrops, application of organic matter and soil conservation to reduce overland water flow into a site (Tenkouano et al., 2006). Weevil build-up can be addressed through mat sanitation, chopping up harvested pseudostems and corms to eliminate weevil refuges, weevil trapping and the inoculation of tissue-cultured plants with a fungal endophyte such as Beauvaria bassiana (Okolle et al., 2008). Suckers sourced directly from the field can be cleaned by paring (removal of the roots and outer layer of the corm) and hot/boiling water treatment $\left(20 \mathrm{~min}\right.$ at $52{ }^{\circ} \mathrm{C}$ or $30 \mathrm{~s}$ at $100{ }^{\circ} \mathrm{C}$; Colbran, 1967; Tenkouano et al., 2006). Although tissue-cultured plants are free of pests and pathogens, the efficacy of clean planting material is reduced when planted into an infested field (Speijer et al., 2000; Elsen et al., 2004; Jacobsen, 2010). Furthermore, roots of tissue-cultured plantlets are more susceptible to early nematode infection than the thicker roots of sucker-derived plants (Waele et al., 1998; Stoffelen et al., 2000). The use of endophytes to protect tissue-cultured plants and reduce nematode damage has been documented in China (Su et al., 2017), East Africa (Waweru et al., 2014) and Costa Rica (Sikora et al., 2008), although commercial use is still limited, especially for smallholders.

For bacterial wilts, the best strategy is preventive management through the use of certified seed and planting in exclusion zones where the disease is not present. In Colombia, CIAT and the Colombian National Federation of Plantain Producers have piloted thermotherapy to ensure bacteria-free plants (Álvarez et al., 2015b; Vitovec, 2015). Field management to reduce the risk of spread of bacterial wilts include the breaking off of the male flower bud to prevent insect vector transmission, regular disinfection of tools, using a solution of $5 \%$ sodium hypochlorite (household bleach) or a $20 \%$ iodine solution or fire (Eyres et al., 2005; Paull \& Duarte, 2011; Blomme et al., 2014). Field recovery from advanced infections of xanthomonas wilt has been validated through a package of practices - removal of diseased stems at first symptoms, male bud removal and tool disinfection. This dramatically reduces the risk of disease spread (Blomme et al., 2017) and new suckers repopulate the mat and field. In export and intensive national market-oriented stands, the risks of propagating of $R$. solanacearum may be reduced by the use of footbaths, containing sodium hypochlorite solution, at farm entrances and between plots. Healthy bunches can be protected with translucent plastic bags to help prevent dissemination by aerial vectors. Rotating with crops that do not host the bacteria such as cassava, maize or beans will also help (Rodríguez \& Avelares, 2012).

For Foc, BBTV and BSV, management practices to reduce spread once disease is present in a field are limited primarily to early detection of the symptoms and eradication of the diseased mats. For Foc the challenge is primarily how to manage the plant residues, which contain spores (Dita et al., 2013), while for BBTV eradication practices should attempt to reduce the dispersal of the resident aphid population. For both diseases, minimizing the emergence of volunteer shoots is critical. Certain agronomic practices have been associated with increased spread of Foc, such as the use of ammonium fertilizers and glyphosate for weed control (Larson et al., 2006). No onfarm practices are available to eliminate or reduce Foc or BBTV once it is present in a sucker. The risk of using suckers from healthy mats in fields with differing percentages of diseased mats has not yet been evaluated. The use of endophytes, organic matter applications and cover crops has been shown to improve plant resistance to Foc and improve production (Dita et al., 2018), but the use of suckers from such fields is still high risk. Heat treatment can be used to eliminate both BSV and BBTV prior to tissue culture multiplication from meristem (shoot tip) culture, although the use of clean material is considered more cost-effective for large-scale laboratories.

The maintenance and enhancement of agrobiodiversity inherent to traditional farming systems often achieve more moderate losses compared with industrial monocrop farming systems (Bridge, 1996; Ploetz, 2015). However, it may not follow that such mixed systems also provide cleaner seed for subsequent planting beyond the regions of production. The specific mechanisms of the suppressiveness of mixed cropping systems (Garret \& Mundt, 1999) and the potential for agroecological intensification (Staver et al., 2018) for managing seed degeneration merit a separate review.

\section{Seed degeneration cycle: from planting material used to planting material extracted}

While the seed degeneration process has been defined as covering multiple crop cycles (Thomas-Sharma et al., 
2016), for bananas, which are often found in perennial stands, the focus here will be on a single cycle (i.e. from planting a sucker until extraction of the next sucker for planting). In reality, there are often several years between consecutive plantings. Here, a cycle is considered to begin with the quality and risk factors of the planting material that is used to plant a new field $(x)$ and ends with the quality and risk factors of the suckers extracted from the field $(x)$ to be used to plant a new field $(x+1$; Fig. 1). Most commonly, farm households extract suckers from their own or neighbouring stands to plant a new field or to fill gaps in an existing field. The quality of the suckers is determined by the physical characteristics of the suckers and characteristics of the specific mats and the field from which they were extracted (field $x-1)$. The new field $(x)$ becomes the source of suckers when planting material is needed to plant a new field $(x+1)$, or to fill gaps within the same field. Seed degeneration in this proposed framework compares the quality and risk factors of two sets of suckers, which are linked to three fields (Fig. 1). At a larger scale, degeneration can be measured comparing the quality and risk factors of material used to plant bananas in a region in the year compared to the quality and risk factors of the planting material extracted from the stands for planting in the next cycle.

Based on this time cycle and the review of six major seedborne pests and pathogens, the following framework is proposed to analyse the rate of seed degeneration $\left(R_{\text {degen }}\right)$ as a function of two sets of quality- and riskimplicated factors:

Input suckers $(x)$ : characteristics of planting material to plant a new field and the mats and field from which the suckers were extracted;

Output suckers $(x+1)$ : characteristics of planting material extracted from field planted with input suckers.

$R_{\text {degen }}=f$ (factors input suckers, factors output suckers).

For locally available suckers, which are used to plant new fields, source factors are (i) cultivar-dependent, because different cultivars will show differing degrees of susceptibility to pests and pathogens; (ii) dependent on the presence of pests and diseases in the field, or region; (iii) the age of the stand; (iv) the pest and disease status of the mats from which suckers are extracted; and $(\mathrm{v})$

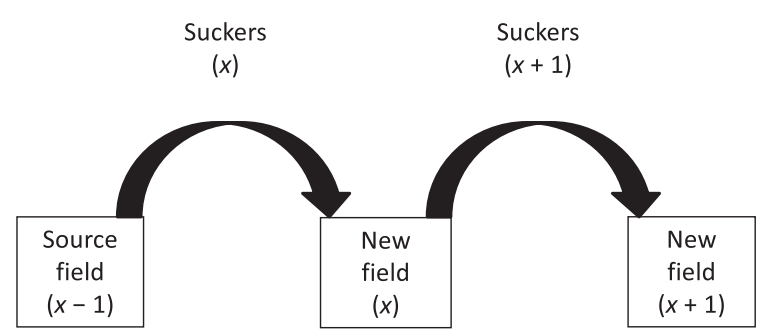

Figure 1 Diagram of the successive cycles of sourcing and using banana planting materials. infection risks during the preparation and transport of planting materials. The suckers that are extracted may be used in different multiplication processes to generate more planting material or material of higher quality which are summarized below.

Input sucker quality

$$
=f(\text { cultivar, pdf, age, mat, sucker, method })
$$

where cultivar $=$ cultivar susceptibility, pdf $=$ pests and diseases in field, age $=$ age of field used as source of planting material, mat $=$ phytosanitary status of mother plant, sucker $=$ practices employed in preparation of sourced suckers, and method = additional multiplication methods used.

This review has highlighted factors that may affect how quickly suckers in a new field (field $x$ in Fig. 1) acquire new or increased infestations of pest and pathogens. Starting with cultivar specificity and input sucker quality, in the new field such factors as the presence of the pest and pathogen in the field to be planted and their proximity in surrounding fields will determine the rate of infection of the new field, with implications both for the productive life of the field and the health of the suckers that can be extracted. For each pest and pathogen, different practices are available to avoid the introduction of new infestations and to limit the internal spread of any existing causal organisms. These include specific pest and pathogen management approaches and crop and soil management strategies. In addition, the severity of the pest or pathogen and crop vulnerability may be under the influence of abiotic factors - extent and distribution of rainfall and related humidity and temperature averages and fluctuations.

$$
\begin{aligned}
& \text { Output sucker quality } \\
& =f(\text { cultivar, presence, nearness, mgt, abiotic })
\end{aligned}
$$

where cultivar $=$ cultivar susceptibility, presence $=$ presence of pest or pathogen in new field to be planted, nearness $=$ nearness of pest or pathogen in surrounding banana fields, $\mathrm{mgt}=$ practices deployed to limit the level of infection and boost plant vigour, and abiotic $=$ weather and soil factors influencing vectors, spores and plant vigour.

\section{Common propagation methods and their value in seed degeneration management}

Five methods are commonly used to source planting material for new banana stands (Table 2). The use of suckers sourced from a nearby field in production is the main method used by most smallholder producers. Such suckers are readily available for timely planting with low transport costs, especially in situations where the areas planted are relatively stable from year to year. The use of locally sourced suckers is also compatible with high cultivar diversity. 
Table 2 Multiplication rates and infrastructure needs for multiplication methods to generate banana planting materials.

\begin{tabular}{|c|c|c|c|c|c|}
\hline $\begin{array}{l}\text { Multiplication } \\
\text { method }\end{array}$ & $\begin{array}{l}\text { Type of planting material } \\
\text { produced }\end{array}$ & $\begin{array}{l}\text { Multiplication } \\
\text { rate per unit }\end{array}$ & $\begin{array}{l}\text { Months to } \\
\text { produce } \\
50000 \\
\text { plants }\end{array}$ & $\begin{array}{l}? \text { tbcolw }=7 p c ?>\text { Infrastructure to } \\
\text { produce } 50000 \text { plants }\end{array}$ & $\begin{array}{l}\text { Conservation of banana } \\
\text { diversity }\end{array}$ \\
\hline $\begin{array}{l}\text { Suckers extracted } \\
\text { from a field in } \\
\text { production }\end{array}$ & Suckers of $0.3-1 \mathrm{~kg}$ & $\begin{array}{l}2-5 \text { per year } \\
\text { per mat }\end{array}$ & $\begin{array}{l}\text { 10-11 } \\
\text { starting } \\
\text { from new } \\
\text { field }\end{array}$ & $\begin{array}{l}2-15 \text { ha of fields in production (planted } \\
\text { at } 1600 \text { plants ha }{ }^{-1} \text { ) }\end{array}$ & Current approach \\
\hline $\begin{array}{l}\text { Multiplication plot } \\
\text { for sucker } \\
\text { production only, } \\
\text { no bunch harvest }\end{array}$ & $\begin{array}{l}\text { Suckers of } 0.3-1 \mathrm{~kg} \\
\text { harvested from single } \\
\text { stem mats at high } \\
\text { density, flowering } \\
\text { prevented }\end{array}$ & $\begin{array}{l}\text { 10-20 } \\
\text { suckers per } \\
\text { mat }\end{array}$ & 20 & $\begin{array}{l}\text { New field planted to produce suckers } \\
\text { (see above; } 10 \text { months) for } 2 \text { ha of } \\
\text { high density planting (10 months) }\end{array}$ & $\begin{array}{l}\text { Compatible and useful } \\
\text { to increase available } \\
\text { suckers }\end{array}$ \\
\hline $\begin{array}{l}\text { Microcorms grown } \\
\text { out in nursery }\end{array}$ & $\begin{array}{l}\text { Plants in nursery bags } \\
\text { grown from small } \\
\text { suckers } 0.2-0.3 \mathrm{~kg} \\
\text { extracted from mat/field } \\
\text { in producing field or } \\
\text { multiplication plot }\end{array}$ & $\begin{array}{l}\text { 10-20 } \\
\text { suckers per } \\
\text { mat }\end{array}$ & $10-22$ & $\begin{array}{l}2-15 \text { ha of fields in production } \\
\text { ( } 8 \text { months) or } 2 \text { ha of multiplication } \\
\text { plots ( } 20 \text { months); suckers in screen } \\
\text { house nursery ( } 2 \text { months) }\end{array}$ & $\begin{array}{l}\text { Compatible with high } \\
\text { cultivar diversity, } \\
\text { although used more } \\
\text { for commercial } \\
\text { production }\end{array}$ \\
\hline $\begin{array}{l}\text { Macropropagation } \\
\text { from secondary } \\
\text { buds on corms }\end{array}$ & $\begin{array}{l}\text { Plants in nursery bags } \\
\text { from sprouts generated } \\
\text { from secondary or } \\
\text { axillary buds on corm } \\
\text { exposed by stripping } \\
\text { with leaf sheaths }\end{array}$ & $\begin{array}{l}\text { 8-60 } \\
\text { plantlets per } \\
\text { corm in high } \\
\text { humidity } \\
\text { chamber }\end{array}$ & $20-28$ & $\begin{array}{l}1 \text { ha of fields for corm production } \\
\text { ( } 10 \text { months) or via sucker } \\
\text { multiplication plot less area needed } \\
\text { (<0.5 ha) but more time (additional } \\
8 \text { months); corms in high humidity } \\
\text { chamber ( } 6 \text { months); plants in screen } \\
\text { house nursery ( } 4 \text { months) }\end{array}$ & $\begin{array}{l}\text { Compatible - multiple } \\
\text { cultivars in single } \\
\text { chamber, small scale } \\
\text { and short turnaround }\end{array}$ \\
\hline Tissue culture & $\begin{array}{l}\text { Plants in nursery bag from } \\
\text { shoot tip extracted from } \\
\text { sucker and proliferated } \\
\text { in laboratory }\end{array}$ & $\begin{array}{l}1000 \\
\text { plantlets } \\
\text { from a } \\
\text { single shoot } \\
\text { tip }\end{array}$ & $\begin{array}{l}\text { 14-44 } \\
\text { depending } \\
\text { on source } \\
\text { of initial } \\
\text { suckers }\end{array}$ & $\begin{array}{l}\text { Suckers from superior mother plants; } \\
\text { tissue culture laboratory; high } \\
\text { humidity weaning nursery; screen } \\
\text { house hardening nursery }\end{array}$ & $\begin{array}{l}\text { Difficult - high cost, } \\
\text { centralized, delay } \\
\text { between order and } \\
\text { delivery }\end{array}$ \\
\hline
\end{tabular}

Cultivars with strong apical dominance, like most plantains, show inhibited sucker development, while cultivars with low apical dominance will produce one or two well-developed suckers (regulated suckering behaviour, e.g. most AAA-East African Highland varieties) or many developing suckers (non-regulated suckering behaviour, e.g. Yangambi km5; Ortiz \& Vuylsteke, 1998). Sucker development is also severely influenced by altitude. Higher suckering is observed at the high altitude areas (even for cultivars with high apical dominance) compared with the low altitude areas (Sikyolo et al., 2013). A seed system based on local exchange and sale of suckers is challenged when markets for a few cultivars are under rapid expansion, when a new cultivar with high market potential is introduced, or when a systemic pathogen becomes a threat.

The other four methods to produce planting material begin with suckers, but thereafter have different multiplication ratios and infrastructure requirements. Their deployment also varies depending on prevailing pests and pathogens (Tables 2 \& 3). Sucker multiplication plots and the use of microcorms are more common among commercial growers for the multiplication of newly introduced cultivars or highly uniform planting material to take advantage of market opportunities.
Multiplication plots stimulate sucker production through destruction of the apical meristem at flower initiation, but before flower emergence (De Langhe, 1961; Wilson et al., 1987). Under optimal management, the resulting suckers can have zero or greatly reduced risk of seed degeneration. Standard suckers for direct planting can be extracted from a multiplication plot, but small, coneshaped suckers (200-300 g), called peepers or microcorms, can also be extracted from a field, treated and then planted into a nursery until plants reach an appropriate size for transplanting (Rosales et al., 2010). Risk of disease transmission for microcorms is lower than for suckers, as more time is needed during preparation and handling of the materials, allowing a higher level of inspection. For both methods, material can be sorted by size to obtain more uniform stands.

Macropropagation, also known as corm fragment shoots or plantes issus de fragments de tiges, is based on the activation of latent axillary buds by physical destruction of the apical dominance (i.e. removal of the apical meristem) and careful removal of leaf sheaths at the point of attachment to the corm (Muñoz \& Vergas, 1996; Kwa, 2003; Njukwe et al., 2007). Suckers of up to $1 \mathrm{~kg}$ are pared and the leaf sheaths are stripped away one by one to expose the axillary buds. The corms are 
Table 3 Key practices to reduce the presence of each pest and pathogen using different multiplication practices.

\begin{tabular}{|c|c|c|c|c|c|}
\hline Pest or pathogen & $\begin{array}{l}\text { Sucker extraction and } \\
\text { preparation }\end{array}$ & $\begin{array}{l}\text { Sucker multiplication } \\
\text { plots }\end{array}$ & $\begin{array}{l}\text { Macropropagation } \\
\text { chamber practices }\end{array}$ & $\begin{array}{l}\text { Tissue culture } \\
\text { laboratory special } \\
\text { practices }\end{array}$ & Nursery practices \\
\hline Nematodes & $\begin{array}{l}\text { Paring or boiling; } \\
\text { extract from young } \\
\text { field }\end{array}$ & $\begin{array}{l}\text { Use of pared suckers, } \\
\text { field free of } \\
\text { nematode infection }\end{array}$ & $\begin{array}{l}\text { Sterile medium as } \\
\text { substrate, sterile tools }\end{array}$ & $\begin{array}{l}\text { No additional } \\
\text { practices }\end{array}$ & $\begin{array}{l}\text { Sterile substrate for } \\
\text { nursery bags }\end{array}$ \\
\hline Weevils & $\begin{array}{l}\text { Paring or boiling; } \\
\text { extract from young } \\
\text { field }\end{array}$ & $\begin{array}{l}\text { Use of pared suckers, } \\
\text { weevil-free field and } \\
\text { neighbouring fields }\end{array}$ & $\begin{array}{l}\text { Additional inspection and } \\
\text { paring of corms }\end{array}$ & $\begin{array}{l}\text { No additional } \\
\text { practices }\end{array}$ & $\begin{array}{l}\text { Barriers to weevil } \\
\text { movement, banana- } \\
\text { free buffer }\end{array}$ \\
\hline BBTV & $\begin{array}{l}\text { Extract from BBTV- } \\
\text { free field }\end{array}$ & $\begin{array}{l}\text { BBTD-free planting } \\
\text { material; banana-free } \\
\text { period prior to } \\
\text { planting and } 100 \mathrm{~m} \\
\text { banana-free buffer }\end{array}$ & $\begin{array}{l}\text { Virus testing of corms } \\
\text { prior to use }\end{array}$ & $\begin{array}{l}\text { Virus testing, } \\
\text { meristem culture }\end{array}$ & $\begin{array}{l}\text { Barriers to aphid } \\
\text { access to plants, } \\
\text { banana-free buffer, } \\
\text { roguing }\end{array}$ \\
\hline BSV in $A A B$ & $\begin{array}{l}\text { Positive selection } \\
\text { within field }\end{array}$ & & No additional practices & $\begin{array}{l}\text { Protocols to } \\
\text { reduce BSV } \\
\text { activation }\end{array}$ & $\begin{array}{l}\text { Roguing of off-type } \\
\text { plants }\end{array}$ \\
\hline $\begin{array}{l}\text { BSV in AAA and } \\
\text { ABB }\end{array}$ & $\begin{array}{l}\text { Extract from BSV-free } \\
\text { field }\end{array}$ & $\begin{array}{l}\text { BSV-free planting } \\
\text { material, banana-free } \\
\text { period prior to } \\
\text { planting }\end{array}$ & $\begin{array}{l}\text { Virus testing of corms } \\
\text { prior to use }\end{array}$ & $\begin{array}{l}\text { Virus testing, } \\
\text { meristem culture }\end{array}$ & $\begin{array}{l}\text { Barrier to mealybugs, } \\
\text { roguing }\end{array}$ \\
\hline $\begin{array}{l}\text { Bacterial wilts } \\
\text { (BXW, moko) }\end{array}$ & $\begin{array}{l}\text { Extract from disease- } \\
\text { free plots for } \\
\text { disease-free zones, } \\
\text { positive selection of } \\
\text { symptomless } \\
\text { suckers, aseptically } \\
\text { extracting and paring } \\
\text { in diseased zones }\end{array}$ & $\begin{array}{l}\text { Clean suckers, } \\
\text { banana-free period } \\
\text { prior to planting, } \\
\text { clean tools during } \\
\text { sucker preparation } \\
\text { and field } \\
\text { management }\end{array}$ & $\begin{array}{l}\text { Additional inspection of } \\
\text { corms prior to use, } \\
\text { sterile medium as } \\
\text { substrate, sterile tools, } \\
\text { soil-free boots }\end{array}$ & $\begin{array}{l}\text { Bacteria testing, } \\
\text { meristem culture } \\
\text { and antibiotics }\end{array}$ & $\begin{array}{l}\text { Sterile substrate and } \\
\text { tools, banana-free } \\
\text { buffer }\end{array}$ \\
\hline Fusarium & $\begin{array}{l}\text { Extract from Foc-free } \\
\text { field }\end{array}$ & $\begin{array}{l}\text { Clean planting } \\
\text { material, Foc-free } \\
\text { field }\end{array}$ & $\begin{array}{l}\text { Sterile medium as } \\
\text { substrate, soil-free boots }\end{array}$ & $\begin{array}{l}\text { Fungus testing, } \\
\text { meristem culture }\end{array}$ & $\begin{array}{l}\text { Sterile substrate for } \\
\text { nursery bags, soil- } \\
\text { free boots, banana- } \\
\text { free buffer }\end{array}$ \\
\hline
\end{tabular}

BBTD, banana bunchy top disease; BBTV, banana bunchy top virus; BSV, banana streak virus; BXW, banana xanthomonas wilt; Foc, Fusarium oxysporum f. sp. cubense.

then placed in a high humidity chamber formed by transparent plastic covering a moist substrate (e.g. sawdust). The resulting sprouts from the latent buds are harvested at regular intervals and transplanted to nursery bags. A corm can average 10-12 sprouts, but up to 60 plantlets can be harvested when the buds of the first round of shoots are removed/scarified, depending on variety (Staver \& Lescot, 2015). Recently, simpler macropropagation units have been proposed, using soil as substrate and mulch or other local covers, which could be an alternative in more remote regions where thick plastic sheets and sawdust are not available or costly (Ntamwira et al., 2017).

Micropropagation or tissue culture is the propagation of banana plantlets from shoot tips under sterile laboratory conditions (Vuylsteke, 1989; Israeli et al., 1995; Singh et al., 2011). This technique has the highest rate of proliferation (1000 plantlets per shoot tip), but also the highest infrastructure requirements (Table 2). Suckers used for the extraction of shoot tips should be sourced from a region free of diseases and subjected to quarantine and inspection. This is also an opportunity to select mother plants with superior traits compared to other plants of the same cultivar. Under controlled laboratory conditions, small corms are pared down and disinfected. The shoot tips are individually excised and transferred to a growth and rooting medium. Each shoot tip gives rise to 3-20 new shoot tips. These are again cultured to multiply at the same rate. The tiny plants are set out in a hardening nursery (high humidity, limited light) for 4 7 weeks, transplanted and moved into a weaning nursery for another 4-7 weeks. Micropropagation of large quantities of banana plantlets can also be achieved efficiently using male floral meristems (Mahadev et al., 2011). Male floral parts are used to generate cell suspension culture and multiplication of secondary somatic embryos. This approach can be used to generate pure lines from single plant cells.

With appropriate practices and under specific conditions, all multiplication methods can produce clean planting material, which serves to reduce the risks of seed degeneration (Table 3). Several sets of practices are common across methods: importance of clean suckers, clean fields or substrates, and adequate buffers to limit 
reintroduction of causal organisms either into fields or nurseries. However, the different methods represent a continuum from high risk to low risk in terms of seed degeneration. Where greater care can be used in selecting and treating the material (i.e. tissue culture), the lower risk of disease results in higher costs of multiplication. A modest tissue culture facility costs up to $\$ 50000$ to equip (Arias et al., 2003). By contrast, the costs for building a standard macropropagation chamber and using it for a year in Africa varies from $\$ 100$ to over $\$ 5000$ (Danso et al., 1999; Njukwe et al., 2007; Ouma et al., 2011). The low cost macropropagation units based on soil as substrate and mulch or simpler frames as cover cost between $\$ 18$ and $\$ 135$, and thus are suitable for smallholder farmers in remote regions that find the standard units to be costly (Ntamwira et al., 2017). For tissue culture, cost per unit of planting material can be reduced in large-scale production. Tissue culture costs are lowest when only a few highly commercial cultivars are multiplied (Table 2), which may work against the conservation of cultivar diversity characteristic of zones of secondary diversity like East Africa (East African Highland bananas) and the Congo Basin (plantain).

\section{Seed degeneration challenges to informal and formal seed flows}

To illustrate the application of the proposed seed degeneration framework, five different banana-growing regions were examined, with different pests and pathogens affecting planting material quality (Table 4). The five cases were compared based on responses to three questions that permit identification of alternative actions taken by banana-growing households and production service providers to reduce the risk of seed degeneration and accompanying yield and livelihood losses. The crosssite responses are the inputs for conclusions about the value of a seed degeneration framework for improving farmer access to healthy seed.

The five cases represent the six different phytosanitary problems for the health of planting material that were discussed earlier. Each site is characterized by a primary threat with other secondary pests and pathogens present as well.

\section{Coastal Peru}

The export Cavendish banana production in desert coastal Peru has relatively few phytosanitary problems, which makes it well suited to organic production (World Banana Forum, 2018). However, the zone has suffered from mealybug-transmitted BSV, which makes fruit unacceptable for export (Pasberg-Gauhl et al., 2007). The effects of BSV are accentuated in certain periods of the year with low temperatures. BSV-infected fruit are sold on the national market.

\section{West Africa}

Plantain is an important food and income crop in Ghana and Cote d'Ivoire in West Africa, grown in bush fallow rotations and as a shade crop in young cocoa plantations (Lescot et al., 2014). Planting material quality is affected principally by weevils and nematodes. Recently, large investment projects to renovate cocoa stands have turned to tissue culture to supply the demand for millions of plantain plants to be planted in the new cocoa fields. This has raised the issue of tissue culture-activated BSV (T. Lescot, CIRAD, Montpellier, France, personal communication).

\section{Central Uganda}

The Pisang Awak beer bananas in central Uganda, grown with little management investment due to their resistance to weevils and nematodes, were decimated by the spread of xanthomonas wilt transmitted from flower to flower by insects (Smith et al., 2008; Rietveld et al., 2013). Although less catastrophic, Pisang Awak in central Uganda is also affected by Foc, which could affect the long-term prospects for the crop because the soil also becomes infested (Gold et al., 2002a; Tushemereirwe et al., 2004).

\section{Amazonian Peru}

Iholena, an all-purpose banana of the South Pacific group of plantains, is very popular in Peruvian urban markets. Isla banana, as it is known in Peru, is grown by farmers on the lower Amazonian slopes of the Central Andes. A field of Isla banana produces two to four harvests before production collapses due to weevils and Foc (Roman, 2012). Farmers move to new fields, sourcing seed from their own fields or from fields of neighbours. Seed is also reported to move across regions as farmers in more recently settled communities seek cash crops.

\section{Congo Basin}

The forest zone of the Congo Basin is the centre of secondary diversity for plantain (AAB), with 119 documented cultivars (Adheka, 2014). The crop is well adapted to forest margin and bush fallow agriculture and is an important component of village food security and income generation. Studies of plantain- and bananagrowing areas in the Congo Basin have shown widespread presence of BBTV (Ngama-Boloy et al., 2014). In some localities, losses to BBTV are nearly complete and banana and plantain are no longer grown, while other areas have only very limited infection. Weevils and nematodes are also commonly found affecting plantain stands.

\section{What actions does the proposed framework highlight to} address seed degeneration?

Certain variables from the seed degeneration $\left(R_{\text {degen }}\right)$ framework appeared with a greater frequency than others in the identification of actions to improve the health of planting material in five cases (Table 5). In four of the five cases, market requirements do not permit a 
Table 4 Assessment of seed system challenges in different regions.

\begin{tabular}{|c|c|c|c|c|c|}
\hline $\begin{array}{l}\text { Primary cultivar and } \\
\text { production system }\end{array}$ & Region & $\begin{array}{l}\text { Primary/(secondary) } \\
\text { seed problems }\end{array}$ & Type of seed used & $\begin{array}{l}\text { Available seed system } \\
\text { infrastructure }\end{array}$ & $\begin{array}{l}\text { Sources of grower } \\
\text { technical assistance }\end{array}$ \\
\hline $\begin{array}{l}\text { Cavendish in perennial } \\
\text { stands for organic export } \\
\text { markets }\end{array}$ & Coastal Peru & Episomal BSV & $\begin{array}{l}\text { Suckers, local and } \\
\text { traders, TC plants }\end{array}$ & $\begin{array}{l}\text { International TC labs, } \\
\text { local TC nursery }\end{array}$ & $\begin{array}{l}\text { Grower and marketing } \\
\text { organizations }\end{array}$ \\
\hline $\begin{array}{l}\text { Plantain for market in } \\
\text { forest/bush rotation, } \\
\text { plantain as shade in } \\
\text { young cocoa fields }\end{array}$ & West Africa & $\begin{array}{l}\text { Nematodes, weevils } \\
\text { (BSV) }\end{array}$ & $\begin{array}{l}\text { Suckers, local project- } \\
\text { based TC plants }\end{array}$ & $\begin{array}{l}\text { Sporadic MP } \\
\text { chambers, } \\
\text { international TC } \\
\text { laboratory }\end{array}$ & Occasional projects \\
\hline $\begin{array}{l}\text { Pisang Awak beer banana } \\
\text { in low maintenance } \\
\text { stands }\end{array}$ & $\begin{array}{l}\text { Central } \\
\text { Uganda }\end{array}$ & $\begin{array}{l}\text { Banana bacterial wilt } \\
\text { (Foc race } 1 \text { ) }\end{array}$ & Suckers, local & $\begin{array}{l}\text { Sporadic MP } \\
\text { chambers, local TC } \\
\text { laboratories and TC } \\
\text { nurseries }\end{array}$ & Very occasional projects \\
\hline $\begin{array}{l}\text { Iholena for market in } \\
\text { temporary stands with } \\
\text { fallow and crop rotation }\end{array}$ & $\begin{array}{l}\text { Amazonian } \\
\text { Peru }\end{array}$ & Foc race 1 (weevils) & $\begin{array}{l}\text { Suckers, local and } \\
\text { traders }\end{array}$ & $\begin{array}{l}\text { Sporadic project MP } \\
\text { chambers, research } \\
\text { TC laboratory }\end{array}$ & Occasional projects \\
\hline $\begin{array}{l}\text { Market plantain and } \\
\text { banana in fields with } \\
\text { forest, bush and savanna } \\
\text { fallows and in backyard } \\
\text { gardens; centre of } \\
\text { plantain diversity }\end{array}$ & Congo Basin & $\begin{array}{l}\text { Banana bunchy top } \\
\text { disease (weevils, } \\
\text { nematodes) }\end{array}$ & $\begin{array}{l}\text { Suckers, local project- } \\
\text { based MP and TC } \\
\text { plants }\end{array}$ & $\begin{array}{l}\text { University TC labs and } \\
\text { MP chambers }\end{array}$ & Occasional projects \\
\hline
\end{tabular}

MP, macropropagation; TC, tissue culture; BSV, banana streak virus; Foc, Fusarium oxysporum f. sp. cubense.

substitution of a more resistant cultivar. Only with Pisang Awak beer bananas might such an approach be applicable, depending on juicing properties and yield and flavour factors for Foc-resistant substitute cultivars. In three cases, available cultivars do not offer notable differences in resistance: BSV in Cavendish, plantains in West Africa and BBTV in the Congo Basin. For the cases with BBTV and Foc, the presence of the pathogen in the field was judged relevant, while the presence in the mat was more relevant for xanthomonas wilt. Stand age was identified for the cases of plantain affected by nematodes and weevils, whereby younger plantations tend to have fewer pests, while sucker preparation was identified as relevant in three cases.

Among the factors for maintaining seed health in the new field to be planted, pest and pathogen presence in the new field is relevant for all five cases (Table 5). The proximity of the pest or pathogen in surrounding fields was most relevant for BBTV, with some importance for the sites with fusarium and bacterial wilts. Crop management factors were most relevant for minimizing the build-up in suckers of nematodes, weevils and bacterial wilt. For BBTV and Foc, practices to reduce the spread of the pathogen within the field are important for production, but the risk for sucker extraction increases rapidly once the first infected plants are detected.

While abiotic factors are clearly an important element for production in all five sites, a clear link was not identified between abiotic factors and sucker health. However, this factor has been maintained in the framework to ensure its consideration under other circumstances.
What multiplication methods are applicable in each case?

Commonly, seed systems are contrasted as informal, local or farmer seed systems and formal seed systems that are maintained by public or commercial entities (Thomas-Sharma et al., 2016). In temperate countries, commercial growers of vegetatively propagated crops such as potato and sweet potato commonly purchase high quality, certified planting material for each new cropping season. The production of healthy planting material has a clear potential contribution in each of the five sites under analysis (Table 5). Off-farm methods are identified for all five of the cases, either tissue culture or macropropagated plants produced from disease-free suckers and then often linked to sucker multiplication plots under strict conditions, with neither pests nor pathogens in the field or nursery substrate or in the surroundings. Such healthy planting material schemes have a greater likelihood of success as part of a market-linked cropping system intensification (Staver et al., 2010). Increased investment in planting material appears less viable in the low-input systems in Amazonian Peru, central Uganda or the Congo Basin, even though these systems produce for the market. More pilot initiatives are needed to innovate healthy seed approaches that bridge formal and informal contexts. A hybrid system linking different methods might be best suited, depending on presence of diseases and available infrastructure. For example, purchased tissue culture plantlets may be used to establish clean mother gardens, which thereafter produce a few cycles of clean suckers for use in macropropagation units or in sucker production plots. Such a 
Table 5 Measures to contribute to planting material health for five cases identified using the seed degeneration analysis.

\begin{tabular}{|c|c|c|c|c|}
\hline Case & Source quality & New cycle quality & $\begin{array}{l}\text { Useful methods for } \\
\text { multiplication }\end{array}$ & $\begin{array}{l}\text { Role of off-farm formal } \\
\text { seed actors and technical } \\
\text { assistance }\end{array}$ \\
\hline $\begin{array}{l}\text { Coastal Peru - organic } \\
\text { export Cavendish } \\
\text { episomal BSV }\end{array}$ & $\begin{array}{l}\text { No suckers for replanting } \\
\text { from fields with BSV }\end{array}$ & $\begin{array}{l}\text { New and replanted fields } \\
\text { from TC plants or } \\
\text { suckers from TC planted } \\
\text { stands }\end{array}$ & $\begin{array}{l}\text { Certified TC plants; } \\
\text { suckers from TC planted } \\
\text { fields }\end{array}$ & $\begin{array}{l}\text { Farmer training in BSV } \\
\text { diagnostics; BSV } \\
\text { monitoring; TC plant } \\
\text { certification }\end{array}$ \\
\hline $\begin{array}{l}\text { West Africa market } \\
\text { plantain - nematode, } \\
\text { weevil, BSV }\end{array}$ & $\begin{array}{l}\text { Suckers from younger } \\
\text { stands; sucker paring or } \\
\text { boiling }\end{array}$ & $\begin{array}{l}\text { Pest/pathogen-free field } \\
\text { for new planting; } \\
\text { management for sucker } \\
\text { quality in production } \\
\text { fields }\end{array}$ & $\begin{array}{l}\text { TC plants BSV-free; } \\
\text { sucker multiplication } \\
\text { plots }\end{array}$ & $\begin{array}{l}\text { Farmer training in sucker } \\
\text { quality and practice; TC } \\
\text { protocol to eliminate BSV }\end{array}$ \\
\hline $\begin{array}{l}\text { Pisang Awak beer banana } \\
\text { - XW, FW }\end{array}$ & $\begin{array}{l}\text { Suckers from fields } \\
\text { without FW and mats } \\
\text { without XW }\end{array}$ & $\begin{array}{l}\text { Land without FW history } \\
\text { (and other pests/ } \\
\text { pathogens); XW } \\
\text { prevention in cropping } \\
\text { practices }\end{array}$ & $\begin{array}{l}\text { Sucker multiplication } \\
\text { plots; MP chambers }\end{array}$ & $\begin{array}{l}\text { Farmer training in XW and } \\
\text { FW; cultivar substitution } \\
\text { for FW susceptible } \\
\text { cultivars }\end{array}$ \\
\hline $\begin{array}{l}\text { Amazonian Peru - market } \\
\text { Iholena AAB South } \\
\text { Pacific (Isla) - FW, } \\
\text { weevils }\end{array}$ & $\begin{array}{l}\text { Suckers from fields } \\
\text { without FW; suckers from } \\
\text { young stands; sucker } \\
\text { paring or boiling }\end{array}$ & $\begin{array}{l}\text { Field without FW history } \\
\text { (and other pests/ } \\
\text { pathogens); mapping FW } \\
\text { risk in surrounding fields }\end{array}$ & $\begin{array}{l}\text { TC plants with sucker } \\
\text { multiplication; MP plants; } \\
\text { endophyte enhancement }\end{array}$ & $\begin{array}{l}\text { Farmer training in FW and } \\
\text { crop intensification; TC } \\
\text { plant multiplication; seed } \\
\text { trade monitoring }\end{array}$ \\
\hline $\begin{array}{l}\text { Congo market plantain - } \\
\text { BBTV, weevils, } \\
\text { nematodes }\end{array}$ & $\begin{array}{l}\text { Suckers from field without } \\
\text { BBTV; sucker paring or } \\
\text { boiling }\end{array}$ & $\begin{array}{l}\text { Banana-free period and } \\
100 \text { m buffer for new } \\
\text { fields; early detection } \\
\text { and roguing with minimal } \\
\text { aphid disturbance }\end{array}$ & $\begin{array}{l}\text { ELISA testing to ensure } \\
\text { BBTV-free suckers for TC } \\
\text { and MP plants; sucker } \\
\text { multiplication plots }\end{array}$ & $\begin{array}{l}\text { Farmer training in design } \\
\text { and management of } \\
\text { fields for clean sucker } \\
\text { multiplication; increased } \\
\text { and decentralized virus } \\
\text { testing facilities, TC } \\
\text { laboratory and MP } \\
\text { chamber capacity }\end{array}$ \\
\hline
\end{tabular}

BBTV, banana bunchy top virus; BSV, banana streak virus; XW, xanthomonas wilt; FW, fusarium wilt; MP, macropropagation; TC, tissue culture.

system would benefit from methods for the assessment of seed quality at each cycle. A breakdown of seed degeneration by site and variety would establish criteria for fields serving as source of suckers, and aid the application of quality management systems akin to a Quality Declared Seed (QDS) system.

\section{What role for off-farm actors from formal seed system and technical assistance?}

From the five cases, three questions are common. How can 'clean' source seed be achieved? How can the small amount of clean source seed be multiplied for widespread use with minimal risk of increased infection? How can growers manage their fields to extend the value of the clean material? These concerns align with three key functions of a seed system: the availability, accessibility and durability of clean planting material. In the context of seed degeneration, a portfolio of on-farm management practices may need complementary services from formal seed providers and technical assistance to ensure seed system resilience.

\section{Challenges regarding availability}

In each of the five cases, creating an initial source of high quality seed was complicated by the cultivar involved, the pest or pathogen of primary concern and the available infrastructure. For example, the organic export banana sector in Peru has easy access to BSV-free Cavendish tissue culture plants. By contrast, for plantain in West Africa, farmers readily implement management practices to produce suckers free from weevils and nematodes. However, the large-scale production of tissuecultured plantain plants as a component in a cocoa regeneration project required the development of specific protocols to address eBSV in plantain. Such protocols integrated testing for BSV in initial suckers, multiplication and retesting, which may take up to 2 years before shoot tips free from eBSV are available for multiplication of plantain plants for field planting (Yvan Mathieu, Vitropic, Montpellier, France, personal communication). Such innovative protocols are not yet widely practised even in large commercial tissue culture labs. For tissue culture multiplication of Pisang Awak beer bananas in Uganda and Peru's Isla plantain, commercial protocols are not yet developed, and demand for plants remains small. Protocols to test for Foc presence in suckers in the multiplication process is time-consuming and uncertain. In addition, tissue-cultured materials have been shown to be more vulnerable to Foc under field conditions than suckers (Dita et al., 2016). Sourcing symptomless suckers from fields in production and multiplication through macropropagation may offer a viable approach. Pilot development projects supported by research capacity 
would appear to be needed to fill this gap to seed health. In contrast to Foc, techniques for detection of BBTV in suckers are commercially available and play an important role in alternative approaches to ensuring an initial supply of clean planting material either through tissue culture or macropropagation. With ELISA testing to ensure that source suckers were BBTV-free, the University of Kisangani used tissue culture and macropropagation to multiply BBTV-free plants and then ensure that resulting plants had not become infected with BBTV during nursery management before distribution to rural communities.

\section{Challenges related to accessibility of healthy seed}

Once an initial source of clean seed has been created, new challenges are encountered, particularly when the pest or pathogen of primary concern is present in the field to be planted and/or in the surrounding fields. Wellmanaged sucker multiplication plots may provide a stepping stone to wider accessibility and combinations of methods are possible, when capital investment is limited (Staver et al., 2010). For eBSV in Peruvian organic banana, the limited movement of mealybugs and the ready availability of BSV-free tissue-cultured plants mean that suckers from tissue culture-planted fields are a lowrisk source of planting material for small-scale growers. The millions of tissue-cultured plants distributed through cocoa renovation projects in Cote d'Ivoire are a potential source to upgrade plantain planting material across major regions of the country, but also depend on crop management. Finally, as mentioned earlier, both BBTV and Foc present serious challenges of site selection and management to ensure low-risk conditions to produce healthy seed. For BBTV, fields must be well isolated from BBTV-infected aphids and be planted in a field free from banana for at least 3 months. Foc has fewer restrictions on the degree of isolation from surrounding fields, but the risk of Foc chlamydospores in the soil can only be addressed through oral recollection by farmers and neighbours of the field to be planted, because no diagnostic tools are available. These more restrictive conditions for sucker multiplication may mean that specialized growers become essential to building a more reliable source of healthy seed.

In each of the cases, regular monitoring of the multiplied planting material for pathogen presence is critical, yet difficult to implement, with no clear actors currently available to address this need. Neither visual inspection nor testing for BSV is carried out in organic banana fields of Peru. During the piloting of the multiplication technique for plantains in Cote d'Ivoire, visual inspections were conducted, but routine testing is not implemented. For BBTV, the need for monitoring has been identified, as larger areas are planted with clean suckers and will then become the source of suckers. Whether this flow of suckers can be maintained relatively free of BBTV is a central question in BBTV recovery, but no monitoring schemes are yet in place.
Challenges related to ensuring durability of the quality of planting material

Improved farmer management of banana fields to extend the value of clean material can primarily be addressed through farmer training, which is the most common action by off-farm actors in Table 5. Farmer training is not considered among the components of a formal seed system, which primarily focuses on different types of seed in the multiplication chain, but can serve to strengthen informal seed quality (Almekinders, 2001). The early identification of pest or pathogen presence, an understanding of disease epidemiology and the accompanying practices to reduce spread, and the role of practices to improve sucker quality in fields planted primarily for production all need to be strengthened to improve seed health in a system that is likely to remain primarily informal in all five cases. In many smallholder production systems, decision-making with regards to crop management practices is carried out by different members of the farm family and hired labour may also have responsibilities for sucker extraction, preparation and mat management (Ajambo et al., 2018). Farming training-design needs to consider local differences in the role of family members and hired labour in crop management and the preparation of planting material. A review of the five cases indicates that the grower training-function is poorly addressed.

\section{Conclusions and future directions}

This review of the applicability of the seed degeneration framework to bananas has provided useful insights both for the design and management of programmes and projects to improve farmer access to healthy seed and research priorities in support of such programmes. This review supports the integrated seed health approach proposed by Thomas-Sharma et al. (2016), which is based on cultivar disease resistance, crop management tools and strategic clean seed replacement. The $R_{\text {degen }}$ qualitative equation indicates that the seed degeneration rate depends on quality factors in the source field from which planting material are taken and management of the resulting crop from which new suckers may be sourced. Further methods of multiplication, beyond the direct use of suckers from banana stands in production, are useful for different situations depending on pests and pathogens present, market orientation and cultivar diversity of the production system and available infrastructure. In the case of small- and medium-holder banana production, integrated seed health should become an additional dimension of integrated crop management in which the quality of suckers for follow-up plantings is considered a central component of crop management.

It is proposed that initiatives to offset banana seed degeneration should integrate the role of off-farm actors into decentralized initiatives rather than attempt to duplicate national seed certification frameworks from other true seed or vegetatively propagated crops. Seed 
certification programmes are almost unknown in banana, although the importance of tissue culture with exhaustive phytosanitary certification is well recognized (Diekmann $\&$ Putter, 1996). Three functions were proposed in building locally adapted seed health initiatives: availability of clean source seed, multiplication of clean source seed to increase widespread accessibility, and farmer capacity for crop management to extend the durability and value of clean seed. In many cases, with adequate crop management to generate clean source seed, the intermediate multiplication step drops out. The intensification of plantain production in Central America and the Caribbean based on crop cycles of one to two harvests has generated, as a by-product, an increased supply of relatively clean planting material. In other situations, with the presence of Foc, BBTV or bacterial wilt, the role of monitoring seed health through periodic diagnostic testing merits both further research and pilot implementation to build low-cost, effective approaches.

Maintaining a low-cost supply of healthy planting material still has numerous research questions to address. Among others, improved or new diagnostic tools, early symptom recognition, risk analysis to guide farmer decision-making and the use of endophytes to enhance seed health will contribute to more flexible, adaptable and resilient planting material health strategies for bananagrowing communities globally.

\section{Acknowledgements}

This work is funded by the CGIAR Research Program on Roots, Tubers and Bananas (CRP-RTB), Seed systems cross crop cluster (CC 2.1). The authors thank Daniella Blake for help with revising the final manuscript.

\section{References}

Adheka J, 2014. Contribution to the Characterization and Classification of the Congo Basin African Plantains (Musa AAB) in the Democratic Republic of Congo. Kisangani: Democratic Republic of Congo: University of Kisangani, $\mathrm{PhD}$ thesis.

Ajambo S, Rietveld A, Nkengla LW et al., 2018. Recovering banana production in bunchy top-affected areas in Sub-Saharan Africa: developing gender-responsive approaches. Acta Horticulturae 1196, 219-28.

Allen RN, 1978. Epidemiological factors influencing the success of rogueing for the control of bunchy top disease of bananas in New South Wales. Australian Journal of Agricultural Research 29, 535-44.

Almekinders CJM, 2001. Increasing the resilience of the farmers' seed system through linkage with the formal sector. In: Sperling L, ed. Targeted Seed Aid and Seed-System Interventions. Kampala, Uganda: ICTA, 69.

Almekinders CJM, Louwaars NP, de Bruijn G, 1994. Local seed systems and their importance for an improved seed supply in developing countries. Euphytica 78, 207-16.

Álvarez E, Pantoja A, Gañán L, Ceballos G, 2015a. Current Status of Moko Disease and Black Sigatoka in Latin America and the Caribbean, and Options for Managing Them. CIAT publication no. 404. Cali, Colombia: Centro Internacional de Agricultura Tropical (CIAT).

Álvarez E, Ceballos G, Gañán L, Rodríguez D, González S, Pantoja A, 2015b. Production of Clean Planting Material for Managing Plantain
Diseases. CIAT publication no. 403. Cali, Colombia: Centro Internacional de Agricultura Tropical (CIAT).

Amorim EP, dos Santos-Serejo JA, Amorim VBO, Ferreira CF, Silva SO, 2013. Banana breeding at Embrapa Cassava and Fruits. Acta Horticulturae 986, 171-6.

Arias P, Dankers C, Liu P, Pilkauskas P, 2003. The World Banana Economy, 1985-2002. Rome, Italy: FAO.

Bakry F, Carreel F, Jenny C, Horry JP, 2009. Genetic improvement of banana. In: Mohan Jain S, Priyadarshan PM, eds. Breeding Plantation Tree Crops: Tropical Species. New York, NY, USA: Springer, 3-50.

Banful B, 2000. Production of plantain, an economic prospect for food security in Ghana. In: Picq C, Fouré E, Frison E, eds. Bananas and Food Security. International Symposium, 1998. Douala, Cameroon: INIBAP, 151-60.

Bentley S, Pegg KG, Moore NY, Davis RD, Buddenhagen IW, 1998. Genetic variation among vegetative compatibility groups of Fusarium oxysporum f. sp. cubense analyzed by DNA fingerprinting. Phytopathology 88, 1283-93.

Black R, Delbeke A, 1991. Moko disease (Pseudomonas solanacearum) of Musa in Belize. Tropical Science 31, 347-53.

Blomme G, Jacobsen K, Ocimati W et al., 2014. Fine-tuning banana Xanthomonas wilt control options over the past decade in East and Central Africa. European Journal of Plant Pathology 139, 265-81.

Blomme G, Ocimati W, Sivirihauma C et al., 2017. A control package revolving around the removal of single diseased banana stems is effective for the restoration of Xanthomonas wilt infected fields. European Journal of Plant Pathology 149, 385-400.

Bortagaray I, Gatchair S, 2012. Accessing and producing tissue-cultured banana plantlets in Costa Rica and Jamaica: insights in the distributive consequences of emerging technologies. Technological Forecasting and Social Change 79, 213-22.

Bridge J, 1996. Nematode management in sustainable and subsistence agriculture. Annual Review of Phytopathology 34, 201-25.

Buddenhagen IW, 1986. Bacterial wilt revisited. In: Persley GJ, ed. Bacterial Wilt Disease in Asia and the South Pacific: Proceedings of an International Workshop Held in Los Baños, Philippines, 1985. Canberra, Australia: ACIAR Proceedings no. 13, 126-43.

Buddenhagen IW, 1994. Banana diseases caused by bacteria. In: Ploetz RC, Zentmyer GA, Nishijima WT, Rohrbach KG, Ohr HD, eds. Compendium of Tropical Fruit Diseases. St Paul, MN, USA: American Phytopathological Society, 15-7.

Buddenhagen IW, 2009. Understanding strain diversity in Fusarium oxysporum f. sp. cubense and history of introduction of 'Tropical Race 4' to better manage banana production. Acta Horticulturae 828, 193-204.

Buddenhagen IW, Elsasser TA, 1962. An insect spread bacterial wilt epiphytotic of Bluggoe Banana. Nature 194, 164-5.

CAB International, 2014. Invasive species Compendium. Ralstonia solanacearum race 2. [http://www.cabi.org/ISC/datasheet/44999]. Accessed 5 September 2015.

Caruana ML, 2015. Diversité, Evolution et Contrôle des Virus des Plantes Tropicales: L'ennemi Peut Aussi Venir de L'intérieur. Montpellier, France: Université Montpellier II, PhD thesis.

Chabrier C, Quénéhervé P, 2003. Control of the burrowing nematode (Radopholus similis Cobb) on banana: impact of the banana field destruction method on the efficiency of the following fallow. Crop Protection 22, 121-7.

Colbran RC, 1967. Hot-water Tank for Treatment of Banana Planting Material. Advisory leaflet no. 924. Queensland, Australia: Division of Plant Industry, Department of Primary Industries.

Côte FX, Galzi S, Folliot M, Lamagnère Y, Teycheney PY, IskraCaruana M-L, 2010. Micropropagation by tissue culture triggers differential expression of infectious endogenous Banana streak virus sequences (eBSV) present in the B genome of natural and synthetic interspecific banana plantains. Molecular Plant Pathology 11, 137-44.

Dahal G, Hughes Jd'A, Thottappilly G, Lockhart BEL, 1998a. Effect of temperature on symptom expression and reliability of banana streak 
badnavirus detection in naturally-infected plantain and banana (Musa spp.). Plant Disease 82, 16-21.

Dahal G, Pasberg-Gauhl C, Gauhl F, Thottappilly G, Hughes Jd'A, 1998b. Studies on a Nigerian isolate of banana streak badnavirus. II. Effect of intraplant variation on virus accumulation and reliability of diagnosis by ELISA. Annals of Applied Biology 132, 263-75.

Dahal G, Ortiz R, Tenkouano A et al., 2000. Relationship between natural occurrence of banana streak badnavirus and symptom expression, relative concentration of viral antigen, and yield characteristics of some micropropagated Musa spp. Plant Pathology 49, 68-79.

Dale J, Paul JY, Dugdale B, Harding R, 2017a. Modifying bananas: from transgenics to organics? Sustainability 9, 333.

Dale J, James A, Paul J-Y et al., 2017b. Transgenic Cavendish bananas with resistance to Fusarium wilt tropical race 4. Nature Communications 8, 1496.

Dallot S, Acuña P, Rivera C et al., 2001. Evidence that the proliferation stage of micropropagation procedure is determinant in the expression of banana streak virus integrated into the genome of the FHIA 21 hybrid (Musa AAAB). Archives of Virology 146, 2179-90.

Daniells J, Thomas JE, Smith M, 1995. Seed transmission of banana streak virus confirmed. Infomusa 4, 7.

Daniells JW, Geering ADW, Bryde NJ, Thomas JE, 2001. The effect of banana streak virus on the growth and yield of dessert bananas in tropical Australia. Annals of Applied Biology 139, 51-60.

Danso WO, Green KR, Adjei-Nsiah S, Afreh Nuamah K, 1999. Financial appraisal of plantain sucker production in Ghana. Musafrica 13, 4-7.

Davis RI, Moore NY, Fegan M, 2001. Blood disease and Panama disease: two newly introduced and grave threats to banana production on the island of New Guinea. In: Bourke RM, Allen MG, Salisbury JG, eds. Proceedings of the Papua New Guinea Food and Nutrition Conference 2000. Canberra, Australia: ACIAR, 26-30.

De Langhe E, 1961. La taxonomie du bananier plantain en Afrique équatoriale. Journal d'Agriculture Tropicale et de Botanique Appliquée 8, 417-49.

Delattre P, 1980. Recherche d'une method d'estimation des populations du charaçon du bananier, Cosmopolites sordidus Germar (Coleoptera: Curculionidae). Acta Oecologia 1, 83-92.

Denny TP, 2006. Plant pathogenic Ralstonia species. In: Gnanamanickam SS, ed. Plant-Associated Bacteria. Dordrecht, Netherlands: Springer, 573-44.

Denny TP, Hayward AC, 2001. Gram-negative bacteria - Ralstonia. In: Schaad NW, Jones JB, Chun W, eds. Laboratory Guide for Identification of Plant Pathogenic Bacteria. St Paul, MN, USA: APS Press, 151-73.

Diekmann M, Putter CAJ, 1996. FAO/IPGRI Technical Guidelines for the Safe Movement of Germplasm, no. 15. Musa 2nd edn. Rome, Italy: Food and Agriculture Organization (FAO) of the United Nations, International Plant Genetic Resources Institute (IPGRI).

Dita M, Waalwijk C, Buddenhagen IW, Souza MT, Kema GHJ, 2010. A molecular diagnostic for tropical race 4 of the banana fusarium wilt pathogen. Plant Pathology 59, 348-57.

Dita M, Echegoyen P, Perez-Vicente L, 2013. Plan de Contingencia ante un Brote de la Raza 4 Tropical de Fusarium oxysporum $f$. sp. cubense en un País de la Región del OIRSA. San Salvador, El Salvador: OIRSA.

Dita M, Nomura E, Damatto E et al., 2016. An integrated approach to reduce yield losses caused by Fusarium wilt of banana in São Paulo, Brazil. In: 5th ISHS - Promusa Symposium: Agroecological Approaches to Promote Innovative Banana Production Systems, 10-14 October 2016. [http://www.promusa.org/tiki-download_file.php?fileId= 2865\&display=y]. Accessed 20 December 2017.

Dita M, Barquero M, Heck D, Mizubuti ESG, Staver C, 2018. Fusarium wilt of banana: current knowledge on epidemiology and research needs towards sustainable management. Frontiers in Plant Science. https://doi.org/10.3389/fpls.2018.01468.

Djialo BD, Lokana J, Ngama F et al., 2016. Systemicity of banana bunchy top viral infection in the Kisangani region of the Democratic
Republic of Congo. African Journal of Agricultural Research 11, 527-32.

Dochez C, Dusabe J, Whyte J et al., 2006. New sources of resistance to Radopholus similis in Musa germplasm from Asia. Australasian Plant Pathology 35, 481-5.

Duncan LW, Moens M, 2006. Migratory endoparasitic nematodes. In: Perry RN, Moens M, eds. Plant Nematology. Wallingford, UK: CAB International, 123-52.

Eden-Green SJ, 1994a. Diversity of Pseudomonas solanacearum and related bacteria in Southeast Asia: new directions for Moko disease. In: Hayward AC, Hartman GL, eds. Bacterial Wilt: The Disease and its Causative Agent, Pseudomonas solanacearum. Wallingford, UK: CAB International, 25-34.

Eden-Green SJ, 1994b. Banana Blood Disease. INIBAP Musa Disease Fact Sheet No. 3. Montpellier, France: INIBAP.

Elayabalan S, Subramaniam S, Selvarajan R, 2015. Banana bunchy top disease (BBTD) symptom expression in banana and strategies for transgenic resistance: a review. Emirates Journal of Food and Agriculture 27, 55-74.

van Elsas JD, van Overbeek LS, Bailey MJ, Schönfeld J, Smalla K, 2005. Fate of Ralstonia solanacearum biovar 2 as affected by conditions and soil treatments in temperate climate zones. In: Allen C, Prior P, Hayward AC, eds. Bacterial Wilt Disease and the Ralstonia solanacearum Species Complex. St Paul, MN, USA: APS Press, 39.

Elsen A, Goossens B, Belpaire B, Neyens A, Speijer P, De Waele D, 2004. Recolonisation by nematodes of hot water treated cooking banana planting material in Uganda. Nematology 6, 215-21.

Espino RC, Magnaye LV, Johns AP, Juanillo C, 1993. Evaluation of Philippine banana cultivars for resistance to Bunchy-top and Fusarium wilt. In: Valmayor RV, Hwang SC, Ploetz R, Lee SC, Roa NV, eds. Proceedings of the International Symposium on Recent Developments in Banana Cultivation Technology, 1992. Los Baños, Philippines: Taiwan Banana Research Institute/INIBAP/ASPNET, 89-102.

Eyres N, Hammond N, Mackie A, 2005. Moko Disease Ralstonia solanacearum (Race 2, Biovar 1). Factsheet, Note: 175. Perth, Australia: Department of Food and Agriculture of Western Australia.

Fegan M, Prior P, 2005. How complex is the Ralstonia solanacearum species complex? In: Allen C, Prior P, Hayward AC, eds. Bacterial Wilt Disease and the Ralstonia solanacearum Complex. St Paul, MN, USA: APS Press, 449-61.

Fourie G, Steenkamp ET, Gordon TR, Viljoen A, 2009. Evolutionary relationships among the vegetative compatibility groups of Fusarium oxysporum f. sp. cubense. Applied and Environmental Microbiology $75,4770-81$.

Garret KA, Mundt CC, 1999. Epidemiology in mixed host populations. Phytopathology 89, 984-90.

Gauhl F, Pasberg-Gauhl C, 1995. Temporal dynamics of banana streak badnavirus (BSV) symptoms in Musa clones in southern Nigeria. Phytomedizin 25, 27.

Gayral P, Iskra-Caruana M-L, 2009. Phylogeny of Banana streak virus reveals recent and repetitive endogenization in the genome of its banana Musa host (sp.). Journal of Molecular Evolution 69, 65-80.

Ghag SB, Shekhawat UKS, Hadapad AB, Ganapathi TR, 2015. Stacking of host-induced gene silencing mediated resistance to banana bunchy top virus and fusarium wilt disease in transgenic banana plants. Current Trends in Biotechnology and Pharmacy 9, 212-21.

Global Invasive Species Database, 2018. Species profile: Banana bunchy top virus (BBTV). [http://www.iucngisd.org/gisd/species.php? sc=141]. Accessed 21 March 2018.

Gold CS, Bagabe MI, 1997. Banana weevil, Cosmopolites sordidus Germar (Coleoptera: Curculionidae) infestations in cooking and beer bananas in adjacent stand in Uganda. African Entomology 5, 103-38.

Gold CS, Messiaen S, 2000. The Banana Weevil Cosmopolites sordidus. Musa Pest Fact Sheet No 4. Montpellier, France: INIBAP.

Gold CS, Night G, Speijer PR, Abera A, Rukazambuga NDTM, 1998. Infestation levels of banana weevil Cosmopolites sordidus Germar (Coleoptera: Curculionidae) in banana plants established from treated propagules in Uganda. African Entomology 6, 253-63. 
Gold CS, Pena JE, Karamura EB, 2001. Biology and integrated pest management for the banana weevil Cosmopolites sordidus (Germar) (Coleoptera: Curculionidae). Integrated Pest Management Reviews 6, 79-155.

Gold CS, Kiggundu A, Abera AMK, Karamura D, 2002a. Diversity, distribution and farmer preference of $M u s a$ cultivars in Uganda. Experimental Agriculture 38, 39-50.

Gold CS, Pinese B, Peña JE, 2002b. Pests of banana. In: Peña JE, Sharp JL, Wysoki M, eds. Tropical Fruit Pests and Pollinators. Wallingford, UK: CAB International, 13-56.

Gold CS, Night G, Ragama PE, Kagezi GH, Tinzaara W, 2004. Field distribution for banana weevil adults in cooking banana stands in Uganda. Insect Science and its Application 24, 242-8.

Gomez E, Alvarez E, Llano G, 2006. Variabilidad genética de Ralstonia solanacearum raza 2, agente causal del Moko de plátano en Colombia. Fitopatología Colombiana 30, 1-7.

Gowen SR, Quénéhervé P, Fogain R, 2005. Nematode parasites of bananas and plantains. In: Luc M, Sikora RA, Bridge J, eds. Plant Parasitic Nematodes in Subtropical and Tropical Agriculture, 2nd edn. Wallingford, UK: CAB International, 611-43.

Harper G, Hart D, Moult S, Hull R, 2002. Detection of Banana streak virus in field samples of bananas from Uganda. Annals of Applied Biology 141, 247-57.

Harper G, Hart D, Moult S, Hull R, 2004. Banana streak virus is very diverse in Uganda. Virus Research 100, 51-6.

Hauser S, 2000. Effects of fertilizer and hot water treatment upon establishment, survival and yield of plantain (Musa, spp., AAB, French). Field Crops Research 66, 213-23.

Hayward AC, 1964. Characteristics of Pseudomonas solanacearum. Journal of Applied Bacteriology 27, 265-77.

Hayward AC, 1991. Biology and epidemiology of bacterial wilt caused by Pseudomonas solanacearum. Annual Review of Phytopathology 29, 65-87.

Hermanto C, Sutanto A, Edison HS et al., 2011. Incidence and distribution of fusarium wilt disease of banana in Indonesia. Acta Horticulturae 897, 313-22.

Hodgetts J, Karamura G, Johnson G et al., 2015. Development of a lateral flow device for in-field detection and evaluation of PCR-based diagnostic methods for Xanthomonas campestris pv. musacearum, the causal agent of banana xanthomonas wilt. Plant Pathology 64, 559-67.

Hooper DJ, Hallmann J, Subbotin S, 2005. Methods for extraction, processing and detection of plant and soil nematodes. In: Luc M, Sikora RA, Bridge J, eds. Plant-parasitic Nematodes in Subtropical and Tropical Agriculture, 2nd edn. Wallingford, UK: CABI Publishing, 5386.

Hwang SC, Ko W, 2004. Cavendish banana cultivars resistant to Fusarium wilt acquired through somaclonal variation in Taiwan. Plant Disease 88, 580-7.

Hyde KD, McCulloch B, Akiew E, Peterson RA, Diatloff A, 1992. Strategies used to eradicate bacterial wilt of Heliconia race 2 in Cairns, Australia following introduction of the disease from Hawaii. Australasian Plant Pathology 21, 29-31.

Ilagan YA, Lavina WA, Natural MP, Raymundo AK et al., 2003. Genetic homogeneity of the banana-infecting strains of Ralstonia solanacearum (Smith) Yabuuchi et al. in the Philippines. Philippine Agricultural Scientist 86, 394-402.

Iskra-Caruana M-L, Baurens FC, Gayral P, Chabannes M, 2010. A fourpartner plant-virus interaction: enemies can also come from within. Molecular Plant-Microbe Interactions 23, 1394- 402.

Iskra-Caruana M-L, Duroy P-O, Chabannes M, Muller E, 2014a. Different partners involved in a common story. Infection, Genetics and Evolution 21, 83-9.

Iskra-Caruana M-L, Chabannes M, Duroy P-O, Muller E, 2014b. A possible scenario for the evolution of Banana streak virus in banana. Virus Research 186, 155-62.
Israeli Y, Lahav E, Reuveni O, 1995. In vitro culture of bananas. Chapter 6. In: Gowen S, ed. Bananas and Plantains. World Crop Series. Suffolk, UK: Chapman and Hall, 147-78.

Jacobsen K, 2010. The Importance of Pratylenchus goodeyi on Bananas and Plantains in the Cameroon Highlands and Development of Cultural Control Methods. Leuven (Heverlee), Belgium: Catholic University Leuven, PhD thesis.

Jones DR, Lockhart BEL, 1993. Banana Streak Disease. Musa Disease Fact Sheet No. 1. Montpellier, France: INIBAP.

Jooste AEC, Wessels N, van der Merwe M, 2016. First Report of banana bunchy top virus in banana (Musa spp.) from South Africa. Plant Disease 100, 1251.

Jose PC, 1981. Reaction of different varieties of banana against bunchy top disease. Agricultural Research Journal of Kerala 19, 108-10.

Kalyebara MR, Ragama PE, Kagezi GH et al., 2006. Economic importance of the banana bacterial wilt in Uganda. African Crop Science Journal 14, 93-103.

Karamura D, Mgenzi B, Karamura E, Sharrock S, 2004. Exploiting indigenous knowledge for the management and maintenance of Musa biodiversity on farm. African Crop Science Journal 12, 67-74.

Karamura E, Kayobyo G, Tushmereirwe W et al., 2010. Assessing the impacts of banana bacterial wilt disease on banana (Musa spp.) productivity and livelihoods of Ugandan farm households. Acta Horticulturae 879, 749-56.

Karanja L, Wangai A, Pathak RS, Harper G, 2013. Effect of environment and cultivar on the expression of banana streak disease symptoms in Kenya. African Journal of Biotechnology 12, 1999-2005.

Kelman A, 1954. The relationship of pathogenicity in Pseudomonas solanacearum to colony appearance on a tetrazolium chloride medium. Phytopathology 44, 693-5.

Kiggundu A, Vuylsteke D, Gold CS, 1999. Recent advances in host plant resistance to banana weevil, Cosmopolites sordidus (Germar). In: Frison EA, Gold CS, Karamura EB, Sikora RA, eds. Mobilization of IPM for Sustainable Banana Production in Africa Proceedings of a Workshop on Banana IPM, 1998. Nelspruit, South Africa: INIBAP, 9-22.

King AMQ, Adams MJ, Lefkowitz EJ, Carstens EB, 2012. Virus Taxonomy: Ninth Report of the International Committee on Taxonomy of Viruses. New York, NY, USA: Elsevier Academic Press.

Kubota R, Vine BG, Alvarez AM, Jenkins DM, 2008. Detection of Ralstonia solanacearum by loop-mediated isothermal amplification. Phytopathology 98, 9-1045.

Kumar PL, Hanna R, Alabi OJ, Vangu GH, Naidu RA, 2011. Banana bunchy top virus in sub-Saharan Africa: investigations on virus distribution and diversity. Virus Research 159, 171-82.

Kumar PL, Selvarajan R, Iskra-Caruana M-L, Chabannes M, Hanna R, 2015. Biology, etiology, and control of virus diseases of banana and plantain. Advances in Virus Research 91, 229-69.

Kwa M, 2003. Activation de bourgeons latents et utilisation de fragments de tige du bananier pour la propagation en masse de plants en conditions horticoles in vivo. Fruits 58, 315-28.

Larson RL, Hill AL, Fenwick A, Kniss AR, Hanson LE, Miller SD, 2006. Influence of glyphosate on Rhizoctonia and Fusarium root rot in sugar beet. Pest Management Science 62, 1182-92.

Lassoudière A, 1974. La mosaïque dite 'à tirets' du bananier Poyo en Côte d'Ivoire. Fruits 29, 349-57.

Lemaire L, 1996. Les Relations Sémiochimiques chez le Charançon du Bananier Cosmopolites sordidus Germar (Coleoptera: Curculionidae) et la Resistance de sa Plante-Hôte, le Bananier. Montpellier, France: Université de Montpellier II, PhD thesis.

Lescot T, Staver C, Picq C, 2014. Tools for improved cropping systems intensification in mixed RTB systems with plantain in West and Central Africa. Workshop Report, CGIAR Research Program on Roots, Tubers and Bananas. Montpellier, France: CGIAR. [http://hdl. handle.net/10568/83434]. Accessed 18 October 2018.

Lheureux F, Carreel F, Jenny C, Lockhart BEL, Iskra-Caruana M-L, 2003. Identification of genetic markers linked to banana streak disease 
expression in inter-specific Musa hybrids. Theoretical and Applied Genetics 106, 594-8.

Lockhart BEL, 1986. Purification and serology of a bacilliform virus associated with a streak disease of banana. Phytopathology 76, 995-9.

Lockhart BEL, Jones DR, 2000. Banana mosaic. In: Jones DR, ed. Diseases of Banana, Abaca and Enset. Wallingford, UK: CAB International, 256-63.

Magee CJ, 1927. Investigation on the bunchy top disease of the banana. Bulletin of the Council for Scientific and Industrial Research 30, 88.

Mahadev SR, Kathithachalam A, Marimuthu M, 2011. An efficient protocol for large-scale plantlet production from male floral meristems of Musa spp. cultivars Virupakshi and Sirumalai. In Vitro Cellular \& Developmental Biology - Plant 47, 611-7.

McSorley R, Parrado JL, 1986. Helicotylenchus multicinctus on bananas: an international problem. Nematropica 16, 73-91.

Messiaen S, 2002. Components of a Strategy for the Integrated Management of the Banana Weevil Cosmopolites sordidus (Germar) (Coleoptera: Curculionidae). Leuven (Heverlee), Belgium: Catholic University Leuven, PhD thesis.

Molina AB, 2004. The National Repository, Multiplication and Dissemination Centers: an instrument to enhance the distribution and adoption of improved varieties within Asia and the Pacific. In: Molina $\mathrm{AB}$, Eusebio JE, Roa VN, van den Bergh I, Maghuyop MA, Borromeo $\mathrm{K}$, eds. Advancing Banana and Plantain R\&D in Asia and the Pacific. Proceedings of the 2 nd BAPNET Steering Committee meeting. Jakarta, 06-07/10/2003. Los Baños, Phillippines: INIBAP-AP, 15-9.

Muharam A, Subijanto, 1991. Status of banana disease in Indonesia. In: Valmayor RV, Umali BE, Bejosano CP, eds. Banana Diseases in Asia and the Pacific, Proceedings of Technical Meeting on Diseases Affecting Banana and Plantain in Asia and the Pacific, 1991, Brisbane, Australia. Los Baños, Philippines: INIBAP, 44-9.

Muñoz C, Vergas H, 1996. Evaluación de la metodología de 'multiplicación rápida' en plátano (Musa, AAB). CORBANA 21, 141-4.

Mwebaze JM, Tusiime G, Tushemerweire WK, Maina M, 2006. Development of a semi-selective medium for Xanthomonas campestris pv. musacearum. African Crop Science Journal 14, 129-35.

Nakato VG, Akinbade S, Kumar LP, Bandyopadhyay R, Beed F, 2013. Development of ELISA for the detection of Xanthomonas campestris pv. musacearum, the causal agent of BXW: banana xanthomonas wilt. In: Blomme G, van Asten P, Vanlauwe B, eds. Banana Systems in the Humid Highlands of Sub-Saharan Africa. Wallingford, UK: CAB International, 93-100.

Namukwaya B, Tripathi L, Tripathi JN, Arinaitwe G, Mukasa SB, Tushemereirwe WK, 2011. Transgenic banana expressing Pflp gene confers enhanced resistance to xanthomonas wilt disease. Transgenic Research 21, 855-65.

Ngama-Boloy F, Ibanda BN, Losimba JK et al., 2014. Assessing incidence, development and distribution of banana Bunchy Top Disease across the main banana and plantain growing regions in the democratic republic of Congo. African Journal of Agricultural Sciences 9, 611-2623

Ngatat S, Hanna R, Kumar PL et al., 2017. Relative susceptibility of Musa genotypes to banana bunchy top disease in Cameroon and implication for disease management. Crop Protection 101, 116-22.

Niyongere C, Ateka EA, Losenge T, Lepoint P, Blomme G, 2011. Screening Musa genotypes for banana bunchy top disease resistance in Burundi. Acta Horticulturae 897, 439-47.

Njukwe E, Tenkouano A, Amah D et al., 2007. Macropropagation of Banana and Plantain. Ibadan, Nigeria: IITA.

Ntamwira J, Sivirihauma C, Ocimati et al., 2017. Macropropagation of banana/plantain using selected local materials: a cost-effective way of mass propagation of planting materials for resource-poor households. European Journal of Horticultural Science 82, 38-53.

Ocimati W, Karamura D, Rutikanga A et al., 2013a. Agronomic practices for Musa across different agro-ecological zones in Burundi, eastern Democratic Republic of Congo and Rwanda. In: Blomme G, van Asten P, Vanlauwe B, eds. Banana Systems in the Humid
Highlands of Sub-Saharan Africa. Wallingford, UK: CAB International, 175-90.

Ocimati W, Ssekiwoko F, Karamura E, Tinzaara W, Eden-Green S, Blomme G, 2013b. Systemicity of Xanthomonas campestris pv. musacearum and time to disease expression after inflorescence infection in East African Highland and Pisang Awak bananas in Uganda. Plant Pathology 62, 777-85.

Ocimati W, Nakato GV, Fiaboe KKM, Beed DF, Blomme G, 2014 Incomplete systemic movement of Xanthomonas campestris pv. musacearum and the occurrence of latent infections in xanthomonas wilt infected banana mats. Plant Pathology 64, 81-90.

Ocimati W, Nakato GV, Fiaboe KKM, Beed F, Blomme G, 2015. Incomplete systemic movement of Xanthomonas campestris pv. musacearum and the occurrence of latent infections in xanthomonas wilt-infected banana mats. Plant Pathology 64, 81-90.

Okolle J, Dubois T, Coyne D, Kyamanywa S, 2008. Endophytic Beauveria bassiana in banana (Musa spp.) reduces banana weevil (Cosmopolites sordidus) fitness and damage. Crop Protection 27, $1437-41$

Ortiz R, Vuylsteke D, 1998. Quantitative variation and phenotypic correlations in banana and plantain. Scientia Horticuturae 72, 239-53.

Ouma E, van Asten P, Umuhoza N, Zagabe R, Katembo-Muhiwa , 2011. Banana Seed Systems in Central Africa: Constraints and CostBenefit Assessments. Survey Report on Banana Macropropagation and Conventional Banana Sucker Trade in Rwanda, Burundi and Eastern DRC. Bujumbura, Burundi: CIALCA.

Pasberg-Gauhl C, Lockhart BEL, Dibos C-MF, Llanque RJC, 2007. Banana streak virus identified for the first time in Peru in Cavendish banana (Musa AAA). Plant Disease 91, 906.

Paull RE, Duarte O, 2011. Tropical Fruits, Volume 1. Crop Production Science in Horticulture, 20. Wallingford, UK: CAB International.

Ploetz RC, 2006. Panama disease: an old nemesis rears its ugly head. Part 2. The Cavendish era and beyond. Plant Health Progress 7, 1. https://doi.org/10.1094/php-2006-0308-01-rv.

Ploetz RC, 2015. Management of Fusarium wilt of banana: a review with special reference to tropical race 4. Crop Protection 73, 7-15.

Ploetz R, Pegg K, 1997. Fusarium wilt of banana and Wallace's line: was the disease originally restricted to his Indo-Malayan region? Australasian Plant Pathology 26, 239-49.

Prasad JS, Seshu Reddy KV, Sikora RA, 1995. Hosts of the banana rootlesion nematode, Pratylenchus goodeyi in East Africa. Nematologica Mediterranea 23, 253-4.

Prior P, Fegan M, 2005. Diversity and molecular detection of Ralstonia solanacearum race 2 strains by multiplex PCR. In: Allen C, Prior P, Hayward AC, eds. Bacterial Wilt Disease and the Ralstonia solanacearum Species Complex. St Paul, MN, USA: APS Press, 4405-14.

Puhalla JE, 1985. Classification of strains of Fusarium oxysporum on the basis of vegetative compatibility. Canadian Journal of Botany 63 , 179-83.

Quénéhervé P, Chabrier C, Auwerkerken A, Topart P, Martiny B, Marie-Luce S, 2005. Status of weeds as reservoirs of plant parasitic nematodes in banana fields in Martinique. Crop Protection 25, 860-7.

Rietveld AM, Mpiira S, Jogo W, Staver C, Karamura EB, 2013. 23 The beer banana value chain in central Uganda. In: Blomme G, van Asten P, Vanlauwe B, eds. Banana Systems in the Humid Highlands of SubSaharan Africa. Wallingford, UK: CAB International, 191-201.

Roberts SJ, Eden-Green SJ, Jones P, Ambler DJ, 1990. Pseudomonas syzygii, sp. nov., the cause of Sumatra disease of cloves. Systematic and Applied Microbiology 13, 34-43.

Rodríguez A, Avelares J, 2012. Informe del Taller de Capacitación: Cultivo y Producción de Plátano y Manejo del Moko en el Plátano. Carazo, Nicaragua: Universidad Nacional Agraria.

Roesmiyanto LH, Hutagalung L, 1989. Blood disease (P. celebesis) on banana in Jeneponto - Sulawesi Selatan. Hortikultura 27, 39-41.

Roman C, 2012. Consideraciones Epidemiológicas para el Manejo de la Marchitez por Fusarium (Fusarium oxysporum $f$. sp. cubense) del 
Banano en la Región Central del Perú. Turrialba, Costa Rica: CATIE, MSc thesis.

Rosales FE, Alvarez JM, Vargas A, 2010. Practical Guide for Plantain Production using High Density Planting - Experiences from Latin America and the Caribbean. Montpellier, France: Bioversity International.

Rukazambuga NDTM, Gold CS, Gowen SR, 1998. Yield loss in East African Highland banana (Musa spp., AAA-EA group) caused by the banana weevil, Cosmopolites sordidus Germar. Crop Protection 17, 581-9.

Rybicki EP, 2015. A top ten list for economically important plant viruses. Brief Review. Archives of Virology 160, 17-20.

Sadik K, Nyine M, Pillay M, 2010. A screening method for banana weevil (Cosmopolites sordidus Germar) resistance using reference genotypes. African Journal of Biotechnology 9, 4725-30.

Sarah JL, Pinochet J, Stanton J, 1996. The Burrowing Nematode of Bananas. Musa Pest Fact Sheet, no. 1. Montpellier, France: INIBAP.

Schulz ES, Folsom D, 1923. Transmission, variation, and control of certain degeneration diseases of Irish potatoes. Journal of Agricultural Research 25, 43-117.

Sequeira L, 1962. Control of bacterial wilt of banana by crop rotation and fallowing. Tropical Agriculture (Trinidad) 39, 211-7.

Shamebo D, 2000. Banana in the southern region of Ethiopia. In: Picq C, Fouré E, Frison E, eds. Bananas and Food Security. International Symposium, 1998. Douala, Cameroon: INIBAP, 119-34.

Sikora RA, Pocasangre L, zum Felde A, Niere B, Vu TT, Dababat AA, 2008. Mutualistic endophytic fungi and in-planta suppressiveness to plant parasitic nematodes. Biological Control 46, 15-23.

Sikyolo I, Sivirihauma C, Ndungo V, De Langhe E, Ocimati W, Blomme G, 2013. Growth and yield of plantain cultivars at four sites of differing altitude in North Kivu, eastern Democratic Republic of Congo. In: Blomme G, Astern P, Vanlauwe B, eds. in the Humid Highlands of Sub-Saharan Africa. Wallingford, UK: CAB International, 48-57.

Singh HP, Uma S, Selvarajan R, Karihaloo JL, 2011. Micropropagation for Production of Quality Banana Planting Material in Asia-Pacific. New Delhi, India: Asia-Pacific Consortium on Agricultural Biotechnology (APCoAB).

Sivirihauma C, Rutikanga A, Murekezi C et al., 2013. Effect of length of fallow period after total uprooting of a xanthomonas wilt-infected banana field on infection of newly established planting materials: case studies from Rwanda and eastern Democratic Republic of Congo. In: Blomme G, van Asten P, Vanlauwe B, eds. Banana Systems in the Humid Highlands of Sub-Saharan Africa. Wallingford, UK: CAB International, 125-30.

Sivirihauma C, Ocimati W, Vutseme L, Blomme G, 2017. Getting a grip on Xanthomonas wilt of banana: symptomless suckers from heavily diseased fields can be used to establish new and productive plantations. African Journal of Agricultural Research 12, 2490-8.

Smith JJ, Jones DR, Karamura E, Blomme G, Turyagyenda FL, 2008. An Analysis of the Risk from Xanthomonas campestris $p v$. musacearum to Banana Cultivation in Eastern, Central and Southern Africa. Montpellier, France: Bioversity International.

Soguilon CE, Magnaye LV, Natural MP, 1995. Bugtok Disease of Banana. Musa Disease Fact Sheet 6. Montpellier, France: INIBAP.

Speijer PR, Sikora RA, 1993. Influence of a complex disease involving Pratylenchus goodeyi and a pathogenic strain of Fusarium oxysporum on banana root health. In: Gold CS, Gemmill B, eds. Biological and Integrated Control of Highland Banana and Plantain Pests and Diseases. Proceedings of a Research Coordination Meeting. Cotonou, Benin: IITA, 218-30.

Speijer PR, Gold CS, Goossens B, Karamura EB, Elsen A, De Waele D, 2000. Rate of nematode infestation of clean banana planting material (Musa spp. AAA) in Uganda. Acta Horticulturae 540, 461-7.

Ssekiwoko F, Turyagyenda LF, Mukasa H, Eden-Green S, Blomme G, 2010. Spread of Xanthomonas campestris pv. musacearum in banana (Musa spp.) plants following infection of the male inflorescence. Acta Horticulturae 879, 349-56.
Stainton D, Martin DP, Muhire BM et al., 2015. The global distribution of banana bunchy top virus reveals little evidence for frequent recent, human-mediated long distance dispersal events. Virus Evolution 1, $1-16$.

Staver C, Capra I, 2017. Banana diversity and the food and income threats of pest and pathogen losses: priority research areas to deploy diversity to reduce pest and disease losses. [https://cgspace.cgiar.org/ bitstream/handle/10568/91529/PIM_Bioversity_MusaDiversity_\% 20FINAL.pdf? sequence=1]. Accessed 18 October 2018.

Staver C, Lescot T, 2015. Propagating Quality Planting Material to Improve Plant Health and Crop Performance, Key Practices for Dessert Banana, Plantain and Cooking Banana: Illustrated Guide. Montpellier, France: Bioversity International.

Staver C, van den Bergh I, Karamura E, Blomme G, Lescot T, 2010. Targeting actions to improve the quality of farmer planting material in bananas and plantains - building a national priority-setting framework. In: Tripathi L, ed. Bananas, Plantains and Enset. I. Tree and Forestry Science and Biotechnology 4, 1-10.

Staver C, Turmel M, Siles P et al., 2018. Step by step tools to identify ecological intensification alternatives for banana cropping systems. Acta Horticulturae 1196, 9-18.

Stoffelen R, Verlinden R, Pinochet J, Swennen RL, De Waele D, 2000. Host plant response of Fusarium wilt resistant Musa genotypes to Radopholus similis and Pratylenchus coffeae. International Journal of Pest Management 46, 289-93.

Stover RH, Espinoza A, 1992. Blood disease of bananas in Sulawesi. Fruits 47, 611-3.

Struik PC, Wiersema SG, 1999. Seed Potato Technology. Wageningen, Netherlands: Wageningen University Press.

Su L, Shen Z, Ruan Y et al., 2017. Isolation of antagonistic endophytes from banana roots against Meloidogyne javanica and their effects on soil nematode community. Frontiers in Microbiology 8, 2070.

Supriadi, 2005. Present status of blood disease in Indonesia. In: Allen C, Prior P, Hayward A, eds. Bacterial Wilt Disease and the Ralstonia Species Complex. St Paul, MN, USA: APS Press, 395-404.

Tarjan AC, 1961. Longevity of Radopholus similis (Cobb) in host free soil. Nematologica 6, 170-5.

Tenkouano A, Hauser S, Coyne DL, Coulibaly O, 2006. Clean planting materials and management practices for sustained production of banana and plantain in Africa. Chronica Horticulturae 46, 14-8.

Thangavelu R, Selvarajan R, Singh HP, 2000. Status of banana streak virus and banana bract mosaic virus diseases in India. In: Singh HP, Chadha KL, eds. Banana: Improvement, Production and Utilization. Proceedings of the Conference on Challenges for Banana Production and Utilization in 21st Century. Trichy, India: AIPUB, NRCB, 364-76.

Thomas JE, 2015. MusaNet Technical Guidelines for the Safe Movement of Musa Germplasm, 3rd edn. Rome, Italy: Bioversity International.

Thomas-Sharma S, Abdurahman A, Ali S et al., 2016. Seed degeneration in potato: the need for an integrated seed health strategy to mitigate the problem in developing countries. Plant Pathology 65, 3-16.

Thompson JP, Owen KJ, Stirling GR, Bell MJ, 2008. Root lesion nematodes (Pratylenchus thornei and P. neglectus): a review of recent progress in managing a significant pest of grain crops in northern Australia. Australasian Plant Pathology 37, 235-42.

Thwaites R, Mansfield J, Eden-Green S, Seal S, 1999. RAPD and rep PCR-based fingerprinting of vascular bacterial pathogens of Musa spp. Plant Pathology 48, 121-8.

Tirado MOI, Zapata CJ, 2003. Resistance of FHIA hybrids to Mycosphaerella spp. InfoMusa 12, 25-8.

Tripathi L, Tripathi JN, 2009. Relative susceptibility of banana cultivars to Xanthomonas campestris pv. musacearum. African Journal of Biotechnology 8, 5343-50.

Tripathi L, Mwaka H, Tripathi JN, Tushemereirwe WK, 2010. Expression of sweet pepper Hrap gene in banana enhances resistance to Xanthomonas campestris pv. musacearum. Molecular Plant Pathology 11, 721-31. 
Tripathi L, Babirye A, Roderick A et al., 2015. Field resistance of transgenic plantain to nematodes has potential for future African food security. Nature Scientific Reports 5, 8127.

Turyagyenda LF, Blomme G, Ssekiwoko F, Karamura E, Mpiira S, Eden-Green S, 2008. Rehabilitation of banana farms destroyed by Xanthomonas wilt in Uganda. Journal of Applied Biosciences 8, 230-5.

Tushemereirwe WK, Kangire A, Kubiriba J, Nakyanzi M, Gold CS, 2004. Diseases threatening banana biodiversity in Uganda. African Crop Science Journal 12, 19-26.

Valencia L, Álvarez E, Castaño J, 2014. Resistencia de treinta y cuatro genotipos de plátano (Musa AAB) y banano (Musa AAA) a cinco cepas de Ralstonia solanacearum raza 2 (Smith). Revista Agronomía 22, 21-34.

Vitovec M, 2015. Clean planting material to combat Moko disease of plantains in Latin America. RTB Blog, 4 September 2015. Montpellier, France: CGIAR. [http://www.rtb.cgiar.org/blog/2015/09/04/clean-pla nting-material-to-combat-moko-disease-of-plantains-in-latin-america/]. Accessed 21 October 2018.

Vuylsteke D, 1989. Shoot-tip Culture for the Propagation, Conservation and Exchange of Musa Germplasm. Practical Manuals for Handling Crop Germplasm in vitro. Rome, Italy: IBPGR.

Waele D, Swennen RL, Boonen E, 1998. Nematode susceptibility and sensitivity of in vitro propagated 'Valery' bananas under field conditions in Costa Rica. Acta Horticulturae 490, 361-8.

Walduck G, Daly A, 2007. Identification of Banana Varieties with Resistance to Fusarium Wilt Tropical Race 4. Report to Horticulture Australia Limited, project no. FR00043 (2007).
Wallace CR, 1938. Measurement of beetle borer migration in banana plantations. Journal of the Australian Institute of Agricultural Sciences 4, 215-9.

Wardlaw CW, 1961. Mosaic, infectious chlorosis and other virus diseases. In: Banana Diseases, Including Plantains and Abaca. London, UK: Longmans, 116-45.

Waweru B, Turoop L, Kahangi E, Coyne D, Dubois T, 2014. Non-pathogenic Fusarium oxysporum endophytes provide field control of nematodes, improving yield of banana (Musa sp.). Biological Control 74, 82-8.

Were E, Nakato GV, Ocimati W, Ramathani I, Olal S, Beed F, 2015. The banana weevil, Cosmopolites sordidus (Germar), is a potential vector of Xanthomonas campestris pv. musacearum in bananas. Canadian Journal of Plant Pathology 37, 427-34.

Wilson GF, Vuylsteke D, Swennen R, 1987. Rapid multiplication of plantain: improved field technique. In: Proceedings of the 3 rd Meeting of the International Association for Research on Plantain and Bananas, 1985. Abidjan, Côte d'Ivoire: INIBAP/IRFA, 24-6.

World Banana Forum, 2018. Organic banana production in Peru. [http:// www.fao.org/world-banana-forum/projects/good-practices/organic-prod uction-peru/en/]. Accessed 10 January 2018.

Ysenbrandt H, Fogain R, Messiaen S, 2000. Infestation levels of weevil species on Musa cultivars Grande Naine (AAA) and French Sombre (AAB) and subsequent plant mortality in Cameroon. African Plant Protection 6, 21-4.

Zuo C, Deng G, Li B et al., 2018. Germplasm screening of Musa spp. for resistance to Fusarium oxysporum f. sp. cubense tropical race 4 (Foc TR4). European Journal of Plant Pathology 151, 723-4. 